Thomas Bonnotte, Sebastien Paul, Marcia Araque-Marin, Robert Wojcieszak*, Franck Dumeignil and Benjamin Katryniok*

\title{
Dehydration of lactic acid: the state of the art.
}

All authors have the same address:

Univ. Lille, CNRS, Centrale Lille, ENSCL, Univ. Artois, UMR 8181-UCCS-Unite de Catalyse et Chimie du Solide, F-59000 Lille, France

Thomas Bonnotte: thomas.bonnotte@centralelille.fr

Sebastien Paul: sebastien.pauul@ec-lille.fr

Marcia Araque-Marin: marcia-carolina.araque-marin@ec-lille.fr

Franck Dumeignil: franck.dumeignil@univ-lille1.fr

${ }^{*}$ Corresponding authors:

Benjamin.katryniok@ec-lille.fr

Robert.wojcieszak@univ-lille1.fr

Abstract: This review presents recent developments in the study of dehydration of lactic acid to acrylic acid. The current state of the art on this subject is presented and critically commented. This paper is based on the most recent publications on the topic, which are discussed in details with respect to the observed catalysts and process performances data. In different catalysts developed, three main groups can be found: zeolites, sulphates and phosphates. The latter, especially hydroxyapatites, have recently attracted the attention of academics in particular. These three families of catalysts are discussed below. The recent developments and the technical drawbacks in the gas phase dehydration are reported. Three main catalysts families are compared and described.

Keywords: lactic acid, dehydration, heterogeneous catalysis, gas phase, hydroxyapatites, 


\section{Introduction}

With a worldwide production of $260 \mathrm{kt} /$ year [1] and $4.7 \mathrm{Mt} /$ year respectively in 2012 [2], lactic and acrylic acids (and their derivatives) are very important products and intermediates for the chemical industry, Europe is the world's second largest producer of lactic acid and acrylic acid. Given the important differences in current production, acrylic acid obtained from lactic acid does not aim to replace acrylic acid deriving from propene in the short-term, but to fulfill an increasing demand by offering an alternative based on renewable resources.

\subsection{Lactic acid: market and applications}

Lactic acid was first identified in 1780 by the Swedish chemist, Carl Whilhelm Scheele [3]. This compound as well as its derivatives are used in many sectors of industry. Today, they are mainly produced by sugar fermentation [4] via anaerobic bacteria. However, the lactic acid can be also produced by chemical reactions, but these processes are not economically viable and a racemic mixture of its enantiomers is obtained, unsuitable for food use. In fact, only the enantiomer $L(+)$ can be metabolised by the human body, as the enantiomer $D(-)$ causes acidosis, in other words a $\mathrm{pH}$ imbalance that drops below natural $\mathrm{pH}$ values evaluated between 7.35 and 7.45) [5] (Scheme 1).

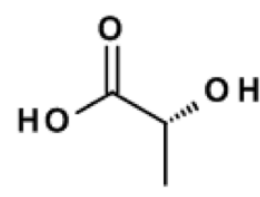

Isomer $D(+)$<smiles>C[C@H](O)C(=O)O</smiles>

Isomer $L(+)$

Scheme 1. $D(-)$ and $L(+)$ enantiomers of lactic acid [6]

The $L(+)$ enantiomer of lacticacid is therefore widely used in the food industry (between 70 and $85 \%$ of the demand for lactic acid) as anacidulent or acifying agent, preservative or antibacterial agent. Although it is a product deriving from the fermentation process, it is sometimes used as an additive to decrease $\mathrm{pH}$ and thus prevent the growth of undesirable micro-organisms [7]. In the pharmaceutical and cosmetic industries, it is used in the composition of topical ointments and creams, and, more generally, skin care taking advantage of its antibacterial properties or even in the composition of oral hygiene products. Initially used for its hygroscopic properties, as a terminating agent for phenoplast resins or involved in the development of adhesives, its recent involvement in the development of biopolymers explains the increasing interest aroused by lactic acid and its derivatives. This shift in demand results in an 
expected production increase of 9\% per year between 2012 and 2017, reaching $367 \mathrm{kt} / \mathrm{year}$ [1]. This is mainly due to an increasing demand for biopolymers that increase threefold between 2012 and 2015 [8]. Blends of lactic acid $D(-)$ and $L(+)$ polymers enable the development of a biodegradable polymer with various properties and applications: polylactic acid PLA. As it is biocompatible, it is used for implants, surgical suture, salting-out systems, control of medicines, etc. They are increasingly replacing daily objects deriving from petrochemicals (PET), such as disposable plastic cups [9].

Lactic acid can also be valorised by chemical routes and, in particular, serves as a precursor to propylene glycol or acrylic acid (Scheme 2), a very important intermediate in the chemical industry, as described in the next section.<smiles>CC(O)C(=O)O</smiles>
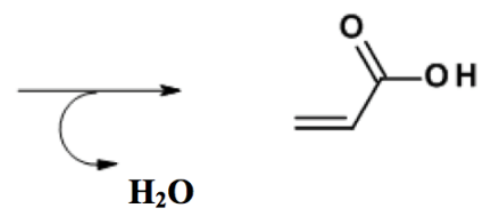

Scheme 2. Scheme of the dehydration reaction of lactic acid to acrylic acid.

\subsection{Acrylic acid: market and applications}

Acrylic acid, prepared for the first time by the oxidation of acrolein in 1843 [10], is a very important intermediate that intervenes in the synthesis of many polymers, paints, absorbents, detergents, adhesives, coatings, etc. There are two main industrial processes for the production of acrylic acid based on two intermediates deriving from petrochemicals: acetylene and propene [11, 12]. However, the acetylene-based process was quickly abandoned for the propenebased one, more cost-effective and easier to implement [12]. On the other hand, the production of propene is very volatile and is constantly on the rise: in 15 years the price per ton has tripled; [13] in Europe, the price per ton of chemical-grade propene increased nearly 60\% in 2014 compared to the price at the beginning of 2013 [14]. These price variations have a direct impact on the price of propene-based acrylic acid (Figure 1) [15].

Figure 1. Impact of the propylene price variations on the price of acrylic acid in Europe $[15,16]$.

Thus, there is a growing interest in using inexpensive resources such as glycerol whose price per ton at the beginning of 2014 (FOB, US) was negotiated at around $\$ 1,091$ (technical-grade glycerol, i.e. with a minimum purity of $98 \%$, 
deriving from vegetal resources), while at the same time propene was almost $40 \%$ more expensive, negotiated at approximately $\$ 1,521[17,18]$ per ton.

\section{Lactic acid production}

Since its discovery, lactic acid is mainly produced by fermentation (in the form of calcium lactate) and was exploited commercially by the Avery Lactate Company in the United States in 1881 [19, 20]. Although there are chemical production routes, they remain unexploited as they are more costly than biochemical methods at present [21]. Moreover, up to now chemical routes only provide racemic mixtures, which is a major defect for the synthesis of polylactic acid requiring maximum chiral purity [22] or regarding its use in the food industry [23]. Below we describes two main routes for lactic acid synthesis.

\subsection{Biochemical routes}

There is a large variety of biochemical routes for the production of lactic acid implementing different types of biocatalysts, processes and substrates and differing by the optical purity obtained, yield, nutritional cost, productivity, etc. The different biocatalysts can be classified according to the following groups:

= Fungi: these biocatalysts of the Rhizopus type (mainly $R$. Oryzae) have many advantages compared to bacteria, such as their natural shape in the form of filaments or pellets simplifying the processes [24], their enantioselectivity for lactic acid $(L+)$ [25], their low nutritive costs (sources of nitrogen, carbon, phosphorus, sulphur and inorganic salts) and their amylolytic properties that enable the direct use of starch without going through the saccharification step [26]. We can thus produce lactic acid from molasses [27], lignocellulosic biomass [28] or starch thanks to fungi. On the other hand, there are still certain obstacles such as the production of by-products [29] (ethanol and fumaric acid) or limits in the transfer of the oxygen necessary for fungi [30].

- Bacteria: bacteria like lactic bacteria (Lactobacillales (lactic bacteria, LAB)), strains of Bacillales (BS), colon bacilli (Escherichia Coli, EC) or even Corynebacterium Glutamicum (CG) [22], whether used under anaerobic or aerobic conditions, produce better yields than with fungi (up to $95 \%$ yield based on fermented sugars) [23]. Homofermentative LABs are preferred (to heterofermentative) for their excellent selectivity to lactic acid. However, they require a complex blend of nutrients. Although very advanced, processes on LABs can be improved by selecting strains more resistant to the acidity of the medium, such as the marine strain Halolactibacillus Halophilus that is active at $\mathrm{pH} 9$ and high temperatures, thus enabling simultaneous saccharification and fermentation (SSF) [31]. The results obtained with BS show that it is 
possible to work at higher temperatures [32] with a high concentration of lactic acid and lower nutritional costs, to perform SSF of the lignocellulosic biomass or even to work with open fermentation [33]. EC has the advantage that it is easy to manipulate genetically and has simple nutritional needs but it is much less resistant to high concentrations of lactic acid. Processes bases on Lab and BS remain more productive in lactic acid, but certain processes based on EC enable the direct production of PLA from glucose [22]. Lastly, genetically modified strains of CG can generate large quantities of lactic acid with high optical purity (I) and enable these strains to work under anaerobic conditions and channel the cell's energy to the synthesis of lactic acid and not to its growth [34].

= Yeasts: yeasts such as Candida, Pichia, etc... are interesting from a process point of view, because they can develop in a mineral medium with very low $\mathrm{pH}$ values. This enables easy recovery of lactic acid, avoiding the use of neutralising agents such as calcium carbonate, the main source of waste in fermentation processes for the synthesis of lactic acid.

= Microalgae or cyanobacteria: few results have been reported on microalgae for the production of lactic acid. However, Hirayama et al. have obtained with Nannochlorum sp. 26A4 D-lactic acid with an optical purity of $99.8 \%$ under anaerobic conditions in the absence of light [22].

\subsection{Chemical routes}

Lactic acid production via the chemical route respresents less than $10 \%$ of production worldwide. Moreover, the commercial process still used (mainly by Musashino) is not based on a renewable resource, but on acetaldehyde (an ethylene product, deriving from petrochemicals) according to the following mechanism [23] (Scheme 3):

1.

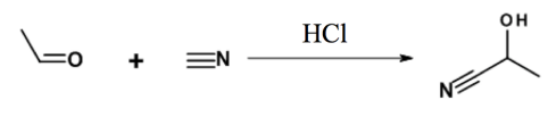

2.

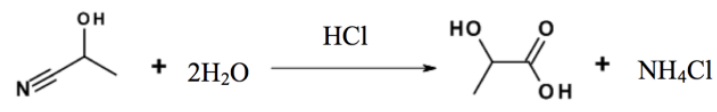

Scheme 3. Lactic acid production from acetaldehyde via actonitrile. Adapted from [23].

The main obstacle to the use of the chemical route is its non-stereospecificity, beyond the differences in cost between the two routes. However, various resources, whether renewable or not, have been studied for the production of 
lactic acid. Scheme 4 presents the different types of resources envisaged for the production of lactic acid via the chemical route [35]:

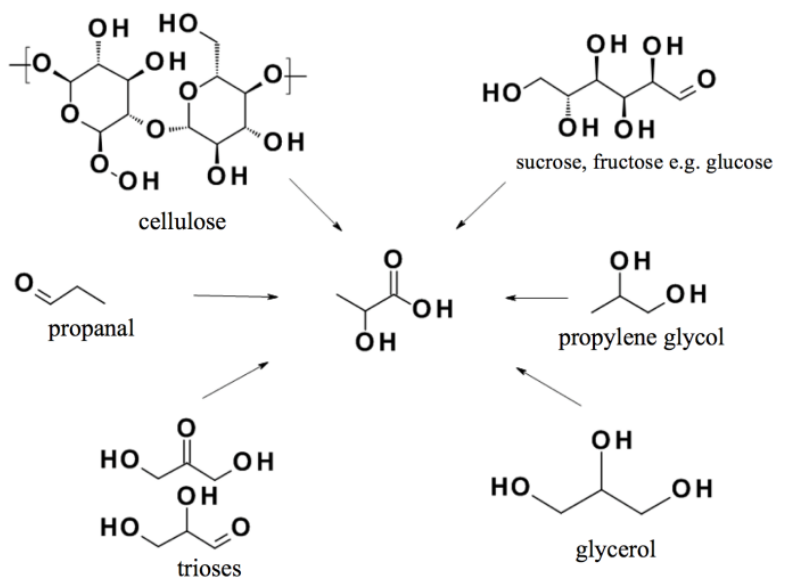

Scheme 4. Various resources envisaged for lactic acid production processes via the chemical route. Adapted from [35].

Chemists inspiration from living things to implement lactic acid production via the chemical route, starting with pyruvaldehyde, which is eliminated in the form of $D$-lactic acid ( $D$-LA) during the metabolic process by all the enzymes of the glyoxalase system. By imitating these enzymes, Eriksen et al. prepared chromium and rhodium complexes with which they succeeded in forming lactic acid from pyruvaldehyde then from GLH and DHA [36]. Later, numerous teams developed different heterogeneous and homogeneous catalysis processes under various conditions (mild chemistry, hydrothermal, etc.):

$=\quad$ Homogeneous catalysis: in 2005, Hayashi et al. obtained a ca. $90 \%$ yield in methyl lactate using tin chloride in methanol at $90^{\circ} \mathrm{C}$ in $3 \mathrm{~h}$. If tin-based catalysts function well in alcohol, they are mediocre in an aqueous medium, because tin salts are relatively poorly soluble and a brown precipitate (probably tin hydroxide [35]) can be observed On the other hand, aluminium and chromium chlorides give yields in lactic acid of 89 and $92 \%$ respectively at $140^{\circ} \mathrm{C}$ in only $1 \mathrm{~h} 30$ [37]. Dusselier et al. then proposed a general mechanism (Scheme 5) for the formation of alkyl lactates in an alcohol medium or lactic acid in an aqueous medium from trioses (GLH and DHA) [35]: 


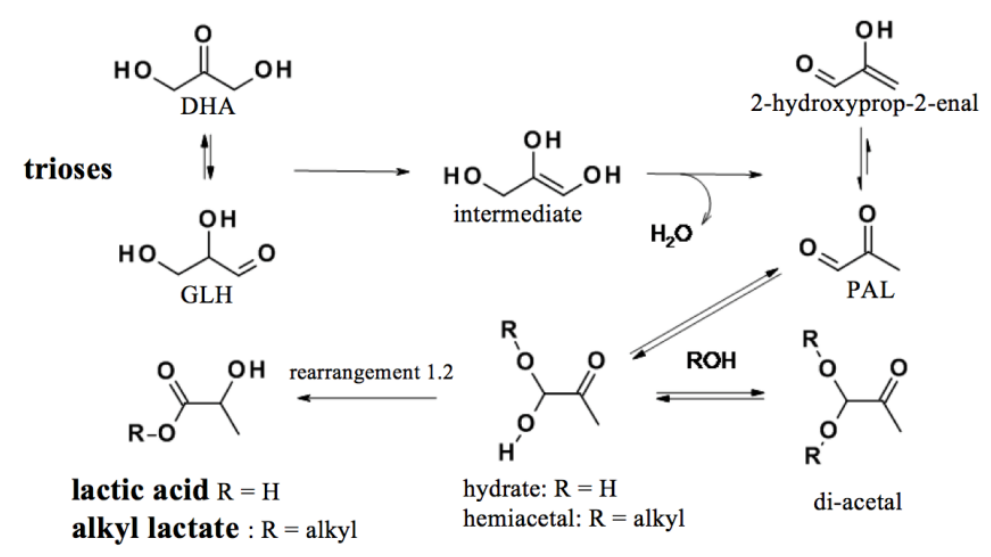

Scheme 5. Conversion mechanisms of trioses to lactic acid or alkyl lactate proposed by Dusselier et al. [35]. Adapted from [35]

= Heterogeneous catalysis: many catalysts have been developed recently, but mainly for the production of lactic esters and not lactic acid, because the reaction is easier in alcohol than in water. By using beta zeolite impregnated with tin, Taarning et al. obtained in water and methanol at $80^{\circ} \mathrm{C}$ yields of $90 \%$ and $99 \%$ respectively. On the other hand, if zeolites are totally stable in methanol, the inevitable appearance of Brønsted sites in water reduces lactic acid yield by $21 \%$ already in the second repetition test. This could be expected as only the Lewis sites have been identified as selective for the synthesis of lactic acid [38]. Other tin-based catalysts [Sn-MCM-41 [39], Sn-CSM [40] (mesoporous silica impregnated with carbon)] also provide yields near or equal to $100 \%$ in alkyl lactates, but the latter drop to values near $75 \%$ in water. The results obtained using heterogeneous catalysts are therefore inferior to those obtained in homogeneous catalysis with aluminium or tin salts [37].

Of course, it is easier to use PAL directly. In fact, we can obtain the desired lactate in aqueous phase in the presence of a base under mild chemical conditions. Jin et al. studied the conversion of biopolyols in aqueous phase using supported metal-based catalysts to obtain a $100 \%$ yield in sodium lactate from PAL $\left(1.1 \mathrm{~mol}^{-1}\right)$ in the presence of $\mathrm{NaOH}\left(2.4 \mathrm{~mol}^{-\mathrm{L}^{-1}}\right)$ in water at only $65^{\circ} \mathrm{C}$ in $30 \mathrm{~min}[41]$.

The production of lactic acid via the chemical route can be carried out from many raw materials deriving from biomass such as cellulose, hexoses and trioses, polyols and aldehydes (proponal, pyruvaldehyde, Scheme 6). Like biochemical routes, processes developed via the chemical route often do not permit direct synthesis of lactic acid, but a salt or an ester, which raises questions for the recovery of the acid form. Moreover, optical purity cannot be obtained with these processes, but only racemic mixtures unsuitable for certain applications, such as polymerisation. Nevertheless, efforts are being made to 
aim towards the higher optical purity given that the increase in the demand for lactic acid is due mainly to the growing interest in PLA. The production of D-LA by fermentation is much less developed than for $L-L A$. But there is a growing interest in incorporating precise quantities of $D$-LA by stereocomplexation with L-PLA polymers to greatly improve the thermal and mechanical properties of polymers obtained at the end. It is very difficult to develop a process that is able to obtain directly a mixture in exact enantiomeric proportions for direct polymerisation. It is essential to develop two distinct production routes for $D-L A$ and $L-L A$. There will therefor be a growing interest in greater $D$-LA productivity, in order to develop more complex polymers with modular properties [35].

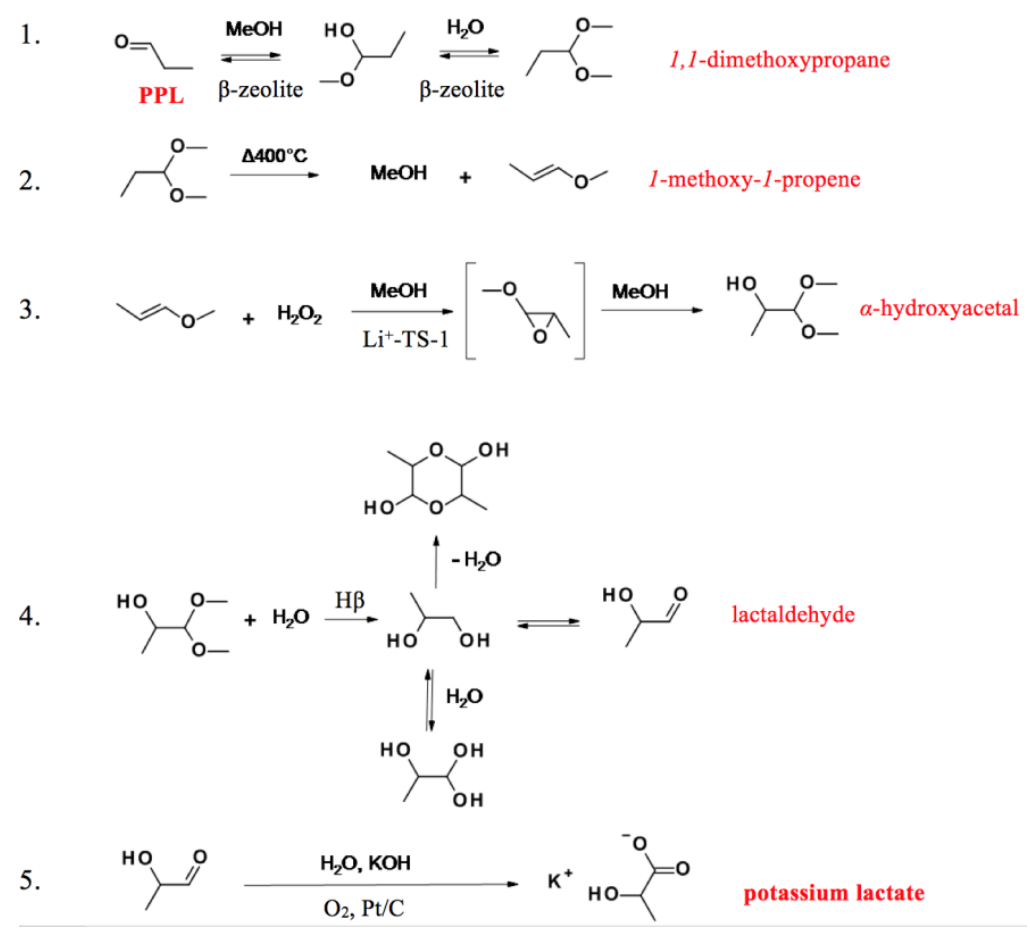

Scheme 6. Steps proposed for the mechanism of synthesis of lactate from propanal. Adapted from [42].

Hadik et al. obtained an enantiomeric excess of $33 \%$ using a supported liquid membrane [43] and even achieve an almost absolute purity in D-LA using a hollow fibre membrane with, however, very low flow rates [44]. Boonpan et al. succeed in obtaining an enantiomeric excess of $63 \%$ at a higher flow rate using a PTFE membrane impregnated with Aliquat ${ }^{\mathrm{TM}} 336$ and chiral selector, $\beta$ cyclodextrine that only associates with $D$-lactic acid [45]. Other solutions can be envisaged, such as the use of enzymes to carry out enantioselective reactions. In 1991, Parida et al. had already performed selective esterification of L-LA, in toluene using butanol and the lipase, Candida Cylindracea. The optical purity measured is nearly total [46]. Most recently, Van Wouwe et al. used a lipase for the enantioselective hydrolysis of a racemic mixture of methyl $D$ and $L$ lactates. They report an enantiomeric excess of $93 \%$ and lay the foundation for the 
production of $D$ and L-PLA via a chemical process combined with a biochemical process, for a 3 fold increase in productivity compared to the most productive biochemical processes [47]. The chemical route is still under development, but definitely has the potential to obtain high productivity of $D$-LA more efficiently than by fermentation. The use of sugars in heterogeneous catalysis to obtain esters avoids the problem of waste generated during fermentation processes. Moreover, processes carry out using heterogeneous catalysts do not require complicated purification steps associated with fermentation such us for example to separate the active catalyst from the reactant solution.

\section{Acrylic acid production}

Acrylic acid is a very useful molecule due to its many applications. About 6 million tons of acrylic acid produced annually [48] now derive exclusively from petroleum resources. In order to satisfy the demand for alternatives based on renewable resources and/or biotechnology processes, research has made significant progress, which even include industrial implementation, such as the recent announcement by Cargill, BASF and Novozymes that they have launched a partnership for the production of "acrylic acid from biomass" [49]. The process combines the production of 3-hydroxypionic acid (3-HPA, a lactic acid isomer) by fermentation of glycerol [50] and dehydration of 3-HPA in acrylic acid, thanks to an acid catalyst [51]. Moreover, lactic acid has been identified as a source of acrylic acid, via both chemical and biochemical routes [35].

\subsection{Biochemical routes}

A considerable effort is being made in the field of bioengineering in order to use micro-organisms to obtain an industrially viable process such as the alliance mentioned above, but also the partnership of OPX-Biotechnologies \& Dow Chemical, who proposes a "bioacrylic acid" production from sugars (dextrose or sucrose) via 3-HPA. The production models are thus identical between the two producer groups [52, 53]. It is however possible to obtain acrylic acid or an acrylate via the biochemical route. Acrylic acid in its acrylate form is an intermediate [54] (in the form of a co-enzyme A ester), in the metabolic system of bacteria such as Clostridium Propionicum, capable of reducing lactate into propionate [55]. Drawn up by Dalal et al., the enzyme scheme is represented below in Scheme 7: 


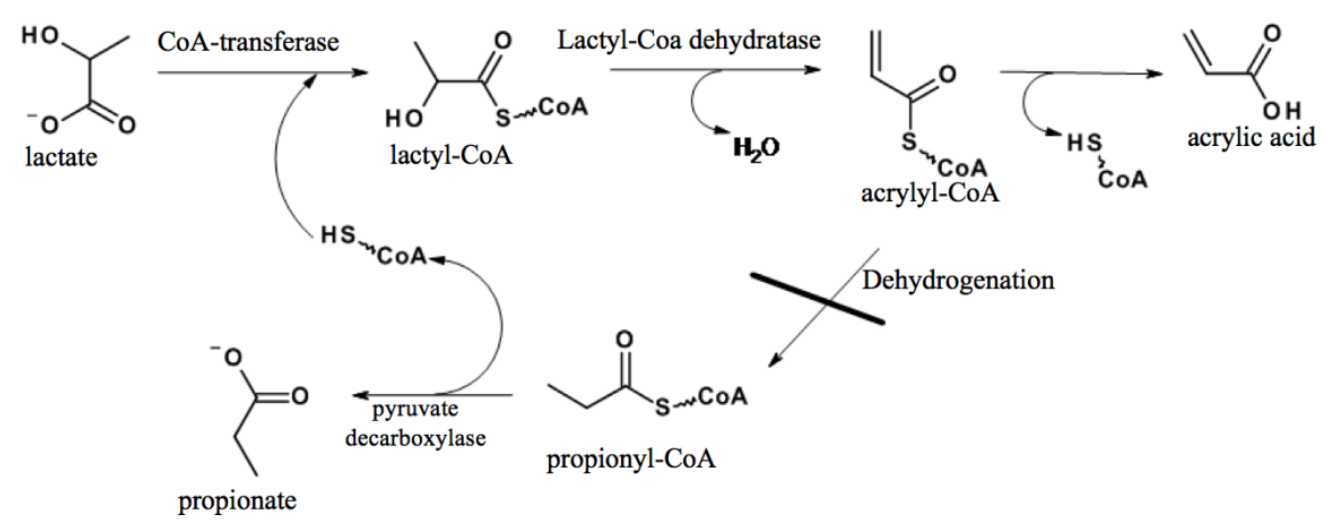

Scheme 7. Simplified scheme of the direct route for metabolic reduction in $C$. Propionicum. Adapted from [56].

By modifying genes involved via the metabolic route for the reduction of $C$. Propionicum or by using blocking agents (such as 3-butynoïc acid), it is possible to avoid dehydrogenase that transforms acrylyl-CoA into propionyl-CoA (symbolised by the backslash). However, the concentrations obtained remain very limited, due to the presence of dehydrogenase that is difficult to block, but also due to the presence of other parallel routes for direct reduction [57]. Moreover, the increase in acrylic acid concentration can inhibit the growth of strains, which is why it is important to select the most resistant mutant strains [58].

Although acrylic acid is identified in the metabolic routes of algae, bacteria and mushrooms, often in its form combined with the co-enzyme A (acrylyl-CoA), for feasibility and productivity reasons, it is sugar fermentation [57] that is mainly studied. The group of Straathof et al. proposes an overview of the routes established or assumed for the production of acrylate from sugars, [59] and represented in Figure 2:

Figure 2. Scheme of the metabolic routes for the biosynthesis of acrylate from sugars. Reprinted with permission from [59].

On the basis of the metabolic routes established, bacterial growth models and a bioethanol production model, the team of Lunelli et al. proposes an acrylic acid synthesis process from glucose via pyruvate and lactate [60]. On the other hand, in 2013 Straathof et al. [61] noted that processes based on enzyme activity always suffer from parallel fermentation as well as the need for an external electron acceptor. Therefore, there is to date no fully biotechnological process for the production of acrylic acid or its esters with a sufficiently high yield that has reached the industrial production stage. 


\subsection{Chemical routes}

Historically produced by several processes based on petro-sourced resources, acrylic acid is now produced by oxidation of propene via acrolein. With the rarefaction of fossil resources, acrylic acid production from molecules deriving from biomass, such as lactic acid or glycerol, is an essential subject as shown by recent publications and process annoucements. Although the current process based on propene is now the main route for the production of acrylic acid, there are other processes sometimes used in the industry:

= Acetylene-based process: this process was the main production process for acrylic acid until the 1980s when due to the cost and availability issues, acetylene was then replaced by propene. The reaction was described in 1939 by Reppe and later used by groups such as Toa Gosei Chemical and Röhm \& Haas. The reaction occurs at $40^{\circ} \mathrm{C}$ under atmospheric pressure in presence of water (acid formation) or alcohol (ester formation), from an acid and nickel tetracarbonyl [11].

This process raises the problem of using nickel tetracarbonyl that is extremely toxic and inflammable. The Reppe process was adapted under high pressure $(13.9 \mathrm{MPa})$ at $200^{\circ} \mathrm{C}$ in the presence of water, $\mathrm{CO}$ and nickel and copper bromide. This process was introduced by BASF and also used by Badische Corp., but it was abandoned in favour of a propene-based process.

$=\quad$ Acrylonitrile-based process: this process leading to ester synthesis is also in fact propene-based, because acrylonitrile is obtained by ammoxydation of propene. If we consider the overall yield of this process on the basis of propene and not acrylonitrile, it appears that the direct process from propene brings a better yield. Moreover, the process based on acrylonitrile produces large quantities of ammonium bisulphate. This process was thus abandoned by several groups such as Ugine Kuhlmann and Mitsubishi Petrochemical. The first step consists in the hydrolysis of acrylonitrile to acrylamide in presence of a copper- and sulphuric acid-based catalyst. It then proceed with the esterification of acrylamide.

$=\quad$ Ketene-based process: this process was abandoned by B. F. Goodrich and Celanese as soon as it was suspected that the intermediate $\beta$ propiolactone was carcinogenic. Moreover, this acetic acid- or acetone-based process involved many steps.

- Ethylene cyanohydrin-based process: this process developed to meet the great demand during WWI was abandoned due to the use of hydrogen cyanide and the production of ammonium bisulphate waste. Ethylene cyanohydrin was produced by the reaction of ethylene oxide with hydrogen cyanide in presence of a basic catalyst. Acrylic acid was then obtained by reacting ethylene cyanohydrin with sulphuric acid. 
= Propene-based process: initially developed as a one-step then twostep process, it is still the most used process in the industry. Propene, relatively inexpensive, is oxidised in one or two steps via acrolein. The reactions are described below [12] (Scheme 8):

1) In one step: $\mathrm{CH}_{2}=\mathrm{CHCH}_{3}+3 / 2 \mathrm{O}_{2} \stackrel{\text { cat. } 1}{\longrightarrow} \mathrm{CH}=\mathrm{CH}_{2} \mathrm{COOH}+\mathrm{H}_{2} \mathrm{O}$

2) In two steps: $-\mathrm{CH}_{2}=\mathrm{CHCH}_{3}+\mathrm{O}_{2} \stackrel{\text { cat. } 2}{\longrightarrow} \mathrm{CH}=\mathrm{CH}_{2} \mathrm{CHO}+\mathrm{H}_{2} \mathrm{O}$

- $\mathrm{CH}=\mathrm{CH}_{2} \mathrm{CHO}+1 / 2 \mathrm{O}_{2} \stackrel{\text { cat. } 3}{\longrightarrow} \mathrm{CH}=\mathrm{CH}_{2} \mathrm{COOH}$

Scheme 8. Equations for the one- or two-step production of acrylic acid from propene. Adapted from [12].

The one-step process was replaced by a two-step due to its higher yield $(85 \%$ versus 50 to $60 \%$ ). Moreover, the catalyst (composed mainly of molybdenum oxide supported on tellurium oxide (Scheme 10, cat. 1) deactivates relatively quickly. The two-step process is as follows: in the first step, propene is oxidised to acrolein at a temperature between $330^{\circ} \mathrm{C}$ and $430^{\circ} \mathrm{C}$ and in the presence of a bismuth molybdate-based catalyst (Scheme 10, cat. 2). The yield of this first step is higher than or equal to $85 \%$. The acrolein formed then reacts in presence of oxygen between $200^{\circ} \mathrm{C}$ and $300^{\circ} \mathrm{C}$, in the presence of a catalyst containing complex molybdenum and vanadium oxides (Scheme 10, cat. 3 ). The yield of this second step on acrolein is generally ca. $100 \%$. Over the years, catalysts have been modified with the addition of many elements such as iron, nickel, bismuth, copper, tellurium and arsenic. These additives activate the reaction at lower temperatures and increase productivity [12]. Many catalysts have been patented among others by Celanese [62], Nippon Kayaku [63], BASF [64], Nippon Shokubai $[65,66]$ etc... Nowadays, the two-step process has supplanted all the others and is the principal means of production of acrylic acid. All of these petrochemical-based processes can be found in the following scheme (Figure 3) [12]:

Figure 3. Overall diagram of routes for the production of acrylic acid and acrylate esters from petrochemicals. Adapted from [12].

The acrolein oxidation to acrylic acid step is already known in the industry, because it is the second step in the propene-based acrylic acid production process. The more complex dehydration of glycerol takes place in gas phase or liquid phase, over an acid catalyst such as zeolites (type ZSM-5 or $\beta$ [67], MFI 
[68, 69], HY [70] or HPA [71]). Recent publications provide an overview of progress in the glycerol dehydration step [72]. The dehydration of glycerol takes place in gas phase or liquid phase, over an acid catalyst such as zeolites (type ZSM-5 or $\beta$ [67], MFI [68, 69], HY [70]). The authors of recent work such as Kim et al., Possato et al. or De Oliveira et al. study the influence of the Si/Al ratio [73] and structure [74]. Acrolein yields are very promising (up to 90\% [75]). The zeolites can be useful due to their malleability in terms of acidity and structure. However, they suffer nevertheless from deactivation with the formation of coke due to limitations of internal diffusion in micropores [76].

Another category of catalysts based on supported heteropolyacids (HPA) are being studied. These polyoxometalate class solids can also see their acid properties adjusted thanks to their modular composition. Due to their small specific intrinsic surface area, they are generally dispersed onto a support such as silica, alumina, zirconia or titanium oxide. There are more than one hundred varieties, [77] but they are mainly clusters of Keggin $\left(\mathrm{H}_{n} \mathrm{X}_{2} \mathrm{M}_{12} \mathrm{O}_{40}\right)$ or Dawson $\left(\mathrm{H}_{n} \mathrm{X}_{2} \mathrm{M}_{18} \mathrm{O}_{62}\right)$ like structures, which are considered for this reaction, where $X$ represents the structure's central non-metallic atom $\left(\mathrm{Si}^{4+}, \mathrm{P}^{5+}\right.$, etc...), and $\mathrm{M}$ the metal species $\left(\mathrm{Mo}^{6+}\right.$ ou $\left.\mathrm{W}^{6+}\right)$. It can sometimes also be substituted with other metallic ions such as $\mathrm{V}^{5+}, \mathrm{Co}^{2+}, \mathrm{Zn}^{2+}$. Depending on the nature of the constituents, we can enhance thermal stability, acidity, oxidation potential or hydrolysis potential [78]. They are now widely studies in bulk form [79], supported [80] or in alkaline salt form [81]. For the recurrent problem of longterm stability of HPAs and dispersion, Katryniok et al. proposed the dispersion of silicotungstic acid onto mesoporous silica on which they had previously grafted zirconia. By optimising the structural parameters of silica according to the work of Tsukuda et al. [82] and by using the zirconia-HPA interaction described by Chai et al. [83] reinforcing the acid properties of HPAs, they propose a catalyst that is stable in the long term, that provides good yield to acrolein (69\% after $24 \mathrm{~h})$ [84], later showing the feasibility of a process including catalyst regeneration phases in presence of oxygen [85]. Likewise, teams have worked on the oxydehydration of glycerol to acrylic acid. Thus, Shen et al. report a $26 \%$ yield in acrylic acid at $300^{\circ} \mathrm{C}$, in presence of mixed oxide $\mathrm{V}_{1} \mathrm{~W}_{0.25}$ [86]. If glycerol seems to offer a promising route for the synthesis of acrylic acid, another molecule derived from biomass enables to obtain acrylic acid via the chemical route, namely lactic acid. As this is the principal topic of this review, this route will be discussed in detail more specifically in the following section.

\section{Gas-phase dehydration of lactic acid to acrylic acid}

The dehydration reaction of lactic acid to acrylic acid in the gas phase was adressed for the first time in 1958 by Holmen in his patent including the production of acrylates by dehydration of lactic acid and alkyl lactates [87]. He reported up to a $68 \%$ yield in acrylic acid with a catalyst consisting of a $\mathrm{Na}_{2} \mathrm{SO}_{4}: \mathrm{CaSO}_{4}$ mixture (molar ratio of $1: 25$ ) at $400^{\circ} \mathrm{C}$ in a $25.4 \mathrm{~cm}$ long Pyrex 
reactor. The patent also reported the reactivity of methyl or butyl lactate, or the use of more concentrated lactic acid solutions, but yields are far below those obtained for lactic acid. The patent disclosed many examples concerning the use of catalysts with a phosphate or pyrophosphate base and alkaline sulphates $(\mathrm{Na}, \mathrm{K}, \mathrm{Cs})$, alkaline earth ( $\mathrm{Ca}, \mathrm{Ba})$ or lanthanide (La). Moreover, Holmen already noted mediocre results (near zero yields with molybdenum-based catalysts) obtained with traditional dehydration catalysts (acid catalysts), namely phosphoric and silico-phosphoric acids, $\mathrm{WO}_{3}, \mathrm{~W}_{2} \mathrm{O}_{5} / \mathrm{Al}, \mathrm{TiO}_{2}, \mathrm{Na}_{2} \mathrm{WO}_{4}$, $\mathrm{Na}_{2} \mathrm{MoO}_{4}, \mathrm{NaVO}_{3}, \mathrm{MoO}_{3}, \mathrm{SiO}_{2}, \mathrm{Al}_{2} \mathrm{O}_{3}, \mathrm{NiMoO}_{2}$ and $\mathrm{ZnMoO}_{3}$. These initial works stress sulphates and phosphates as more or less effective catalysts for the dehydration of lactic acid or lactates to acrylic acid or acrylates, and note that traditional dehydration catalysts in the chemical industry are not selective at all in acrylic acid, which shows the particularity of lactic acid dehydration.

The dehydration reaction of lactic acid to acrylic acid is thoroughly studied in the gas phase in one step, but also in water under supercritical and subcritical conditions [88] even indirectly (acetoxylation of lactic acid to 2acetoxypropionic acid that is then pyrolysed to acrylic acid) [89]. The dehydration reaction can be represented simply according to the following scheme (Scheme 9):<smiles>CC(O)C(=O)O</smiles>

lactic acid

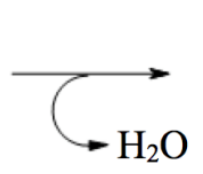

$\mathrm{H}_{2} \mathrm{O}$

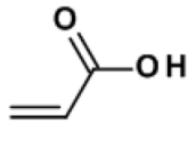

acrylic acid

Scheme 9. Scheme of the dehydration of lactic acid to acrylic acid.

However, in both gas or liquid phase, there are parallel and secondary reactions to dehydration limiting selectivity to acrylic acid. The parallel reactions of decarboxylation or decarbonylation of lactic acid to acetaldehyde are particularly limiting. Moreover, hydrogen derived from the decarboxylation reaction of lactic acid can lead to secondary reactions of reduction of lactic acid or acrylic acid to propionic acid. The formation of acetaldehyde is favoured compared to the formation of acrylic acid with activation energies of $115 \mathrm{~kJ}^{-\mathrm{mol}^{-}}$ 1 and $137 \mathrm{~kJ} \mathrm{~mol}^{-1}$, respectively, according to the calculations of Wadley et al. [90]. The different reactions in play in the conversion of lactic acid are represented in Figure 4 [90]:

Figure 4. Possible occuring products during the conversion of lactic acid to acrylic acid. 
The formation of acetaldehyde is often attributed to the presence of average to strong acid sites during the dehydration of lactic acid in gas phase in presence of a catalyst [91]. This is also the case during the conversion of lactic acid in water under supercritical or subcritical conditions, which are potentially very acid [92]. Lactic acid is thus easily converted into acetaldehyde. The other products (2,3-pentanedione, acetic acid, possibly lactide and hydroxyacetone) are generally formed in less quantities. Due to parallel or secondary reactions, it is difficult to obtain high yields in acrylic acid and the catalyst thus plays an essential role in the orientation of selectivity options. However, it is not the only obstacle, because in aqueous solutions of lactic acid, many chemical species are also present that are likely to react upstream, inside and downstream from the reactor. Indeed, according to mass concentration in lactic acid, oligomers form in solution and their proportion increases with lactic acid concentration [93]. Commercial solutions of lactic acid are labelled with a titration of "about $90 \%$ mass in lactic acid". When preparing a diluted solution with a very concentrated solution, re-establishment of the equilibrium between lactic acid and its oligomers must be taken into account. This also raises the question of equilibrium between lactic acid and its oligomers in the condensates obtained at the output of the reactor at $4^{\circ} \mathrm{C}$, given that oligomers may have formed during evaporation of the lactic acid solution. These incertitudes are not negligible in calculations carried out to evaluate conversion and selectivity options. Therefore, one can assume that the process employed and the operating conditions imposed may have an influence on the distribution of species entering and leaving the reactor. These obstacles to the formation of acrylic acid from lactic acid have produced many publications on the subject since Holmen's patent [87]. The different teams have worked not only to develop a selective catalyst for acrylic acid, but also to understand the reaction mechanism in play, which would enable further development of the process and catalysts. In the different catalysts developed, 3 main groups can be found: zeolites, sulphates and phosphates. The latter, especially hydroxyapatites, have recently attracted the attention of academics in particular. These 3 families of catalysts are discussed below.

\subsection{Dehydration reaction over zeolites}

As a result of the Holmen patent [87], other catalysts were found to be selective for the dehydration of lactic acid to acrylic acid, such as zeolites. In 1993, Takafumi et al. filed a patent application reporting the use of zeolites for a process to prepare unsaturated carboxylic acids or their esters [94]. Following their unsuccessful attempts with silica and silica-alumina, they obtain the best results using synthetic Faujasite ( $\mathrm{X}$ or $\mathrm{Y}$ ) zeolites. Some examples of compositions of these catalysts are given for $\mathrm{NaX}$ or $\mathrm{NaY}$ zeolites:

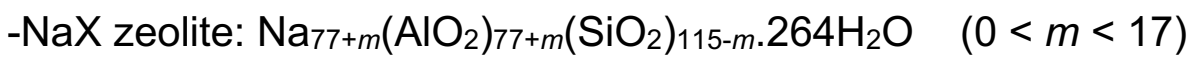


-NaY zeolite: $\mathrm{Na}_{56+n}\left(\mathrm{AlO}_{2}\right)_{56+n}\left(\mathrm{SiO}_{2}\right)_{136-n} \cdot 264 \mathrm{H}_{2} \mathrm{O} \quad(-8<n<20)$

Faujasite zeolites are defined by their composition ([Ca, $\mathrm{Na}, \mathrm{Mg}], \mathrm{Si} \mathrm{Al}$ ) and their characteristic structure called "sodalite": tetrahedrons $\left[\mathrm{SiO}_{4}\right]^{4-}$ and $\left[\mathrm{AlO}_{4}\right]^{5-}$ combined in a crystal lattice forming cavities called supercages, as shown in the following figure (Figure 5) [95]:

Figure 5. Representation of the crystal structure of $X$ and $Y$ zeolites. Adapted from [95]

Differing in composition, $X$ and $Y$ zeolites are distinguished by the Si/Al ratio. For a $\mathrm{Si} / \mathrm{Al}$ ratio $\approx 1.25$, it is called an $\mathrm{X}$ zeolite. For a ratio equal or greater than 3 , it is called a $Y$ zeolite [96]. The author also tests a commercial zeolite called molecular sieve $13 \mathrm{X}^{\circledR}$ with a composition given for $1 \mathrm{Na}_{2} \mathrm{O}: 1 \mathrm{Al}_{2} \mathrm{O}_{3}: 2.8 \pm 0.2$ $\mathrm{SiO}_{2}: x \mathrm{H}_{2} \mathrm{O}$ [97]. The designation $\mathrm{NaY}$ indicates that all charge defects in the crystal structure are compensated not by $\mathrm{H}^{+}$but by $\mathrm{Na}^{+}$. The authors tested also the dehydration of methyl lactate (ML) to methyl acrylate (MA). If Holmen et al. obtain lower yields in acrylic acid and acrylates by using lactic acid esters, Takafumi et al. succeed in achieving much higher yields: they vaporise a solution of methyl lactate in methanol $(50 \mathrm{wt} \%)$ under dinitrogen flow directly (through a pre-heated layer upstream from the catalytic bed) in a quartz reactor with an internal diameter of $1.5 \mathrm{~cm}$ and a length of $45 \mathrm{~cm}$ heated to $240^{\circ} \mathrm{C}$. The catalytic bed is made up of $10 \mathrm{~g}$ of molecular sieve $13 \mathrm{X}^{\circledR}$ and they obtain a $99 \%$ conversion with $93 \%$ selectivity to MA and $2 \%$ to acrylic acid. The process is very effective and is only carried out at $240^{\circ} \mathrm{C}$, but, as other research will show, the dehydration of esters is easier than that of acid. The inventors do not report any example including the dehydration of lactic acid and it is therefore difficult to estimate process performances. On the other hand, they demonstrate the possibility of studying zeolites as lactic acid dehydration catalysts. In addition to these first results, confirmed by other research on the dehydration of alcohol [98] or methyl $\alpha$-hydroxyisobutyrate (a molecule similar to methyl lactate) on zeolites modified at with $\mathrm{K}^{+}$and $\mathrm{Cs}^{+}$[99], the team of Huang studied zeolites modified for the dehydration of lactic acid to acrylic acid [100]. They published a first study on the dehydration of ML to MA over NaY zeolites ( $\mathrm{Si} / \mathrm{Al}=4.5$; Shanghai Hengye Molecular Sieve Co. Ltd.) modified by ionic exchange with $\mathrm{KCl}(\mathrm{KNaY})[101]$. Under conditions very similar to those of Takafumi and in an identical quartz reactor[94], they observed a slight drop of conversion (from $88.6 \%$ to $83 \%$ ) between $\mathrm{NaY}$ and $\mathrm{KnaY}$, but in particular a sharp increase of selectivity to MA, which increases from $32.1 \%$ to $45.7 \%$. The authors tried to explain this difference of selectivity by studying the acidity of their catalysts through the absorption of pyridine followed by infrared spectroscopy (FTIR) and 
by ammonia-temperature programmed desorption (TPD-NH $\mathrm{N}_{3}$ ). FTIR study revealed the presence of Lewis acid sites and the absence of Brønsted sites. In contrast, they observed no significant difference between the two catalysts. On the other hand, TPD- $\mathrm{NH}_{3}$ showed a difference in strength of acid sites. For these two catalysts, two desorption peaks $\left(T_{m 1}\right.$ and $\left.T_{m 2}\right)$ were observed at relatively low temperatures (Table1):

Table 1. Data of TPD-NH $\mathrm{N}_{3}$ over $\mathrm{NaY}$ and $\mathrm{KNaY}$ zeolites [101]

\begin{tabular}{lll}
\hline Catalyst & $T_{m 1}\left({ }^{\circ} \mathrm{C}\right)$ & $T_{m 2}\left({ }^{\circ} \mathrm{C}\right)$ \\
\hline $\mathrm{NaY}$ & 185 & 275 \\
$\mathrm{KNaY}$ & 158 & 258 \\
\hline
\end{tabular}

This data shows that the strength of NaY Lewis acid sites, initially not very high, dropped further after ionic exchange with potassium. According to the authors, there would therefore be a decrease in the strength of the acid sites favouring the formation of acrylic acid. However, they do not discuss any basicity generated by the substitution of $\mathrm{Na}^{+}$with $\mathrm{K}^{+}$nor the evolution of the number of acid sites. They then try to improve performances obtained with $\mathrm{KNaY}$ by optimising the reaction temperature between 280 and $370^{\circ} \mathrm{C}$. All the catalytic results obtained are presented in Table 2.

Table 2. Catalytic performances of $\mathrm{NaY}$ and $\mathrm{KnaY}$ for the dehydration of methyl lactate to methyl acrylate [101].

\begin{tabular}{lllll}
\hline Catalyst $^{[a]}$ & $T\left({ }^{\circ} \mathrm{C}\right)$ & Conv. $(\%)$ & Select. (\%) & Yield (\%) \\
\hline $\mathrm{NaY}$ & 340 & 88.6 & 32.1 & 28.4 \\
$\mathrm{KNaY}$ & 280 & 71.5 & 48.1 & 34.4 \\
& 310 & 72.2 & 45.8 & 33.1 \\
& 340 & 83.0 & 45.7 & 37.9 \\
& 370 & 85.2 & 37.2 & 31.7 \\
\hline
\end{tabular}

[a] LHSV: $0.4 \mathrm{~h}^{-1}$ 
Two opposite trends with the temperature increase can be clearly seen: increase of conversion from (71.5 to $85.2 \%)$ and a decrease of selectivity to methyl acrylate (from 48.1 to $37.2 \%$ ). We can note in particular the significant difference of selectivity between 340 and $370^{\circ} \mathrm{C}$, which would explain the very poor performances obtained by Takafumi with lactic acid esters [94]. If data is insufficient, it can be assumed that low temperatures favour the formation of MA, but beyond a temperature threshold, the formation of acetaldehyde is favoured. Assuming that dehydration needs the participation of an acid site on the model of the formation of acetaldehyde, it will be difficult to obtain high conversion associated with good selectivity at the same time. The catalysts developed must be very selective to acrylic acid (or ester), but, if possible, capable of working at moderate temperatures to prevent the formation of acetaldehyde. Later, Hunag et al. worked on the modification of zeolites to improve the selectivity to acrylic acid of these catalysts. Huang et al. began to modify the same $\mathrm{NaY}$ zeolites with lanthanides, by incipient wetness impregnation with lanthanide nitrate solutions (La, Ce, Sm and Eu) [102]. The authors study the impact of impregnation (nature of lanthanide, impregnation rates...) on catalytic performances, as well as on basic or acid properties (nature and density of sites). The catalytic results obtained are presented in Table 3.

Table 3. Selectivities observed by Huang et al. over zeolites modified by lanthanide impregnation [103].

\begin{tabular}{lllll}
\hline Catalyst & $\begin{array}{l}\mathrm{AA}^{[\mathrm{b}]} \\
(\%)\end{array}$ & $\begin{array}{l}\mathrm{AC}^{[\mathrm{c}]} \\
(\%)\end{array}$ & $\mathrm{PA}^{[\mathrm{d}]}(\%)$ & Others $^{[\mathrm{e}]}(\%)$ \\
\hline $\mathrm{NaY}$ & 34.8 & 16.1 & 1.6 & 47.5 \\
$0.5 \% \mathrm{La} / \mathrm{NaY}$ & 45.3 & 10.4 & 2.1 & 42.2 \\
$1 \% \mathrm{La} / \mathrm{NaY}$ & 43.8 & 6.8 & 1.7 & 47.7 \\
$2 \% \mathrm{La} / \mathrm{NaY}$ & 56.3 & 12.3 & 1.6 & 29.8 \\
$3 \% \mathrm{La} / \mathrm{NaY}$ & 50.2 & 11.9 & 2.3 & 35.6 \\
$4 \% \mathrm{La} / \mathrm{NaY}$ & 44.9 & 18.5 & 3.4 & 33.2 \\
$2 \% \mathrm{Ce} / \mathrm{NaY}$ & 45.8 & 9.5 & 2.0 & 42.7 \\
$2 \% \mathrm{Sm} / \mathrm{NaY}$ & 36.0 & 12.8 & 2.0 & 49.2 \\
$2 \% \mathrm{Eu} / \mathrm{NaY}$ & 40.2 & 16.1 & 3.3 & 40.4 \\
\hline
\end{tabular}

[a] Conversion was $100 \%$ in all cases, conditions: $350^{\circ} \mathrm{C}$, LHSV: $3 \mathrm{~h}^{-1}, \mathrm{~N}_{2}: 30 \mathrm{~mL} \cdot \mathrm{min}^{-1}, \mathrm{~m}_{\text {Cat: }} 1.5$ g, Lac. A. sol: $38 \mathrm{wt} \%$, TOS: $360 \mathrm{~min}$, [b] selectivity to Acrylic Acid, [c] selectivity to Acetaldehyde, 
[d] Selectivity to Propionic Acid, [e] Selectivity to others (COx and unknown products)

These results give much information: they show the ability of modified zeolites to selectively convert lactic acid to acrylic acid. The best result was obtained with $2 \% \mathrm{La} / \mathrm{NaY}$, with a total conversion of lactic acid for a $56.3 \%$ selectivity to acrylic acid. Lanthanum enables a much higher acrylic acid selectivity than with other lanthanides. Given that it is the lower molar mass element, the question can be asked: if it is not due to the difference in the quantity of the elements? It could also be a question of size (ion ray and/or oxidation state). The authors vary the rate of lanthanum impregnation to find a $2 \%$ optimum in mass. This rate will be adopted in other publications of the group [104]. If results are remarkable, it can be noted that the authors were not able to interpret them fully, with a very high proportion of products classified as "others" (Ot.). After analysis by GC and GC-MS, the authors estimated that the gas phase at the trap outlet contains acrylic acid, acetaldehyde and $\mathrm{CO}_{\mathrm{x}}$. The authors also tested acrylic acid conversion under the same conditions, in order to differentiate $\mathrm{NaY}$ from $2 \% \mathrm{La} / \mathrm{NaY}$. Over $\mathrm{NaY}$, acrylic acid is converted to $31 \%$ (products not described) while the conversion is almost nul for $2 \% \mathrm{La} / \mathrm{NaY}$. By observing the colour of the two catalysts after the test, they deduced that the formation of coke drops significantly thanks to the presence of lanthanides that limit the secondary reactions of acrylic acid decomposition. Lastly, the authors tried to study the influence of the method of preparation. They prepared two zeolites containing $2 \%$ of lanthanum. One by incipient wetness impregnation $(2 \% \mathrm{La} / \mathrm{NaY})$ and the other by hydrothermal synthesis (2\%La-NaY). They thereby hoped to understand where lanthanum is located in the zeolite. Indeed, the different sites accessible to lanthanum in the faujasite structure of $\mathrm{NaY}$ are represented in Figure 6 below [105]:

Figure 6. Representation of the different accessible sites to ions outside the crystal structure of $\mathrm{NaY}$ zeolites [105].

According to Nery et al., Na migrates towards site $\mathrm{S} 4$ in the supercage, while La and Ce migrate towards S2 located in the sodalite cage [106]. The authors then suggest that the improvement in catalytic performances would be due, either to charge effects $\left(\mathrm{La}^{3+}\right.$ has a higher oxidation state than $\left.\mathrm{Na}^{+}\right)$, or because sites located in the sodalite cage including a lanthanum are more selective to acrylic acid. By preparing the zeolite in presence of $\mathrm{La}^{3+}$, the authors suggested that $\mathrm{La}^{3+}$ integrates the crystal structure (by substituting aluminium), thereby totally modifying zeolite properties as represented in Figure 7: 
Figure 7. Representation of possible localisations of lanthanum according to the method of preparation of zeolites [107].

In the continuation of their first work, they also assessed the acid properties of zeolites modified by TPD- $\mathrm{NH}_{3}$. The results obtained are presented in Table 4:

Table 4. Assessment of the acidity of zeolites by $\mathrm{TPD}^{-\mathrm{NH}_{3}[103]}$

\begin{tabular}{lccccc}
\hline \multirow{2}{*}{ Catalyst } & $\begin{array}{c}\text { Acid sites } \\
\left.\left(\mu \mathrm{mol}_{\mathrm{g}}\right)^{-1}\right)\end{array}$ & $\begin{array}{c}\text { Total acidity } \\
\left(\mu \mathrm{mol} . \mathrm{g}^{-1}\right)\end{array}$ & $\begin{array}{c}\text { Density of acid sites } \\
\left(\mu \mathrm{mol} . \mathrm{m}^{-2}\right)\end{array}$ \\
\cline { 2 - 5 } & $\mathrm{W}^{[a]}$ & $\mathrm{M}^{[\mathrm{b}]}$ & $\mathrm{S}^{[\mathrm{c}]}$ & & \\
\hline $\mathrm{NaY}$ & 837 & 664 & 34 & 1535 & 3.1 \\
$2 \% \mathrm{La} / \mathrm{NaY}$ & 826 & 485 & 35 & 1346 & 2.5 \\
$2 \% \mathrm{Ce} / \mathrm{NaY}$ & 711 & 471 & 25 & 1207 & 2.4 \\
$2 \% \mathrm{Sm} / \mathrm{NaY}$ & 680 & 527 & 23 & 1230 & 1.9 \\
$2 \% \mathrm{Eu} / \mathrm{NaY}$ & 727 & 614 & 30 & 1371 & 2.1 \\
$2 \% \mathrm{La} / \mathrm{NaY}$ & 711 & 471 & 25 & 1207 & 2.4
\end{tabular}

[a] W: Weak $\left(100-200^{\circ} \mathrm{C}\right)$, [b] M: Medium $\left(201-400^{\circ} \mathrm{C}\right)$, [c] S: Strong $\left(401-600^{\circ} \mathrm{C}\right)$

A sharp drop in basic density for lanthanides modified catalysts as compared to $\mathrm{NaY}$ was observed. Nevertheless, the authors assumed that the fact that $2 \% \mathrm{La} / \mathrm{NaY}$ has kept a sizeable number of weak acid sites could be an explanation of the good performance of the catalyst. The decrease of acidity is considered an advantage to avoid secondary reactions. With these results, Huang et al. identify a new family of selective catalysts towards acrylic acid during lactic acid dehydration. They obtain a maximum yield to acrylic acid of $56.3 \%$ at $350^{\circ} \mathrm{C}$ with a $2 \%$ impregnated $\mathrm{NaY}$ zeolite in lanthanum mass. Huang team continued its research on the basis of these initial conclusions on the modifications of NaY zeolites by lanthanides. They note that these induce a drop in density and strength of acid sites and modify the nature of the reaction site, either by a charge effect or by a modification of structural properties (modification of the sodalite cage). Huang et al. expanded their research on modified zeolites by exploring the effects induced by potassium and alkaline earth on lactic acid dehydration in the gas phase [108]. They went further in the interpretation of their results by studying the impact of impregnation on the basic properties of zeolites and proposed a reaction mechanism. Zeolites were 
prepared based on the conclusions drawn from previous research: incorporation by incipient wetness impregnation of a zeolite around $2 \%$ in mass. The first series of catalysts [109] is prepared with potassium nitrate. In the second series [110], the impregnation rate is not indicated. The catalytic results obtained are presented in Table 5.

Table 5. Results of catalytic tests carried out by Huang et al. over zeolites modified by potassium [111]

\begin{tabular}{|c|c|c|c|c|c|c|c|}
\hline \multirow{2}{*}{ Catalyst } & \multirow{2}{*}{$\begin{array}{l}\text { Conversion } \\
(\%)\end{array}$} & \multicolumn{6}{|c|}{ Selectivity (\%) } \\
\hline & & $\overline{\mathrm{AA}^{[\mathrm{a}]}}$ & $A C^{[b]}$ & $\mathrm{PA}^{[\mathrm{c}]}$ & $2,3 \mathrm{P}^{[\mathrm{d}]}$ & Coke & Ot.[e] \\
\hline$\overline{\mathrm{NaY}}(\mathrm{Si} / \mathrm{Al}=2.5)$ & 96.1 & 14.8 & 10.8 & - & - & na & na \\
\hline $0.35 \mathrm{~K} / \mathrm{NaY}$ & 95.9 & 20.6 & 10.2 & - & 3.5 & na & na \\
\hline $0.7 \mathrm{~K} / \mathrm{NaY}$ & 96.4 & 31.2 & 8.3 & 2.1 & 4.8 & na & na \\
\hline $1.4 \mathrm{~K} / \mathrm{NaY}$ & 97.5 & 39.8 & 6.6 & 4.1 & 9.4 & na & na \\
\hline $2.1 \mathrm{~K} / \mathrm{NaY}$ & 98.2 & 40.2 & 4.7 & 4.0 & 10.1 & na & na \\
\hline $2.8 \mathrm{~K} / \mathrm{NaY}$ & 98.2 & 50 & 2.8 & 3.8 & 10 & na & na \\
\hline $3.5 \mathrm{~K} / \mathrm{NaY}$ & 98.8 & 41.3 & 1.4 & 3.5 & 10.6 & na & na \\
\hline$\overline{\mathrm{NaY}}(\mathrm{Si} / \mathrm{Al}=4.5)$ & 96.3 & 35.94 & 20.2 & - & 8 & 29.4 & 6.5 \\
\hline $\mathrm{KF} / \mathrm{NaY}$ & 91.2 & 39.9 & 17.1 & - & - & 19.3 & 23.7 \\
\hline $\mathrm{KCl} / \mathrm{NaY}$ & 97.1 & 53.8 & 10 & 3.9 & 10.4 & 17.4 & 4.5 \\
\hline $\mathrm{KBr} / \mathrm{NaY}$ & 97.1 & 59.9 & 9.2 & - & 8.1 & 15.7 & 7.1 \\
\hline $\mathrm{KI} / \mathrm{NaY}$ & 97.6 & 67.9 & - & - & 7.9 & 13.0 & 11.2 \\
\hline $\mathrm{KNO} / \mathrm{NaY}$ & 98 & 58.2 & 6.8 & 2.6 & 10 & 17.8 & 4.6 \\
\hline $\mathrm{KSO} 4 / \mathrm{NaY}$ & 94.8 & 51.6 & 20.2 & - & - & 18.1 & 10.1 \\
\hline $\mathrm{KHPO}_{4} / \mathrm{NaY}$ & 94.5 & 49.7 & 6 & - & 6.5 & 20.9 & 16.9 \\
\hline $\mathrm{K}_{2} \mathrm{C}_{2} \mathrm{O}_{4} / \mathrm{NaY}$ & 94.4 & 48.5 & 14.8 & - & 6.5 & 14.8 & 15.4 \\
\hline $\mathrm{K}_{2} \mathrm{CO}_{3} / \mathrm{NaY}$ & 95.1 & 46.7 & 14.7 & - & 4.9 & 13.8 & 19.9 \\
\hline $\mathrm{KOH} / \mathrm{NaY}$ & 96.3 & 44.2 & - & - & - & 13.8 & 42 \\
\hline
\end{tabular}


[a] selectivity to Acrylic Acid, [b] selectivity to Acetaldehyde, [c] Selectivity to Propionic Acid, [d] Selectivity to 2,3-Pentadione, [e] Selectivity to others (COx and unknown products).

The excellent yields to acrylic acid in the two series with a maximum of $66.2 \%$ after 2 hours over $\mathrm{KI} / \mathrm{NaY}(4.5)$ and $49.1 \%$ after 6 hours over $2.8 \mathrm{~K} / \mathrm{NaY}(2.5)$ were obtained. The importance of the nature of the precursor used was observed. Acrylic acid selectivity thus varies from $39.9 \%$ with potassium fluoride to $67.9 \%$ with potassium iodide. Although remarkable, these results should be seen in perspective because, if acrylic acid selectivity is high at first, it drops rapidly despite constant conversion. This evolution is presented in Figure 8.

Figure 8. Evolution during lactic acid conversion time and acrylic acid selectivity over potassium modified zeolites. Adapted from [111].

It is interesting to note that for $3.5 \mathrm{~K} / \mathrm{NaY}$ and $\mathrm{KI} / \mathrm{NaY}$, selectivities remain the same after 6 hours. Given that the conversion is very stable, but selectivity drops drastically, it can be assumed significant coke deposits whose presence is shown after 2 to 3 hours of reaction, limiting transfers and obstructing access to selective acrylic acid sites. Moreover, the authors note a very significant decrease in porous volume and specific surface, which tends to prove that selective conversion to acrylic acid takes place in the sodalite cage. It can be also wonder why in situ generation of water during dehydration does not disturb the initial position of the $\mathrm{K}^{+}$ion in the initially dehydrated catalyst? To explain the properties of their catalysts, Huang et al. attempt to elucidate the assumption formulated in their previous research: impregnation with potassium or lanthanum disturbs the crystal structure locally and modifies acid and basic properties of the zeolite. If the substitution of $\mathrm{Na}^{+}$with $\mathrm{K}^{+}$does not appear to disturb the crystal structure, it definitely has an impact on acido-basic properties. Through the experiments with TPD- $\mathrm{NH}_{3}$ and $\mathrm{TPD}-\mathrm{CO}_{3}$, the authors obtain the results presented in Tables 6 and 7 [109]:

Table 6. Acid properties of K/NaY zeolites (Si/Al: 2.5) determined by TPD-NH [109]

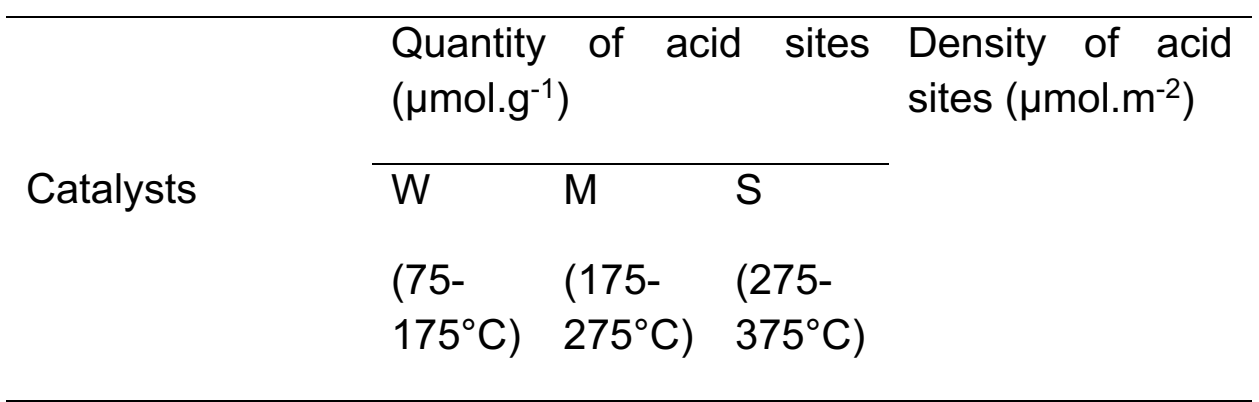




\begin{tabular}{lllll}
\hline $\mathrm{NaY}$ & 905 & 1445 & 244 & 3.6 \\
$0.35 \mathrm{~K} / \mathrm{NaY}$ & 965 & 1539 & 140 & 3.7 \\
$0.7 \mathrm{~K} / \mathrm{NaY}$ & 975 & 1360 & 62 & 3.3 \\
$1.4 \mathrm{~K} / \mathrm{NaY}$ & 822 & 984 & 21 & 2.7 \\
$2.1 \mathrm{~K} / \mathrm{NaY}$ & 711 & 690 & 8 & 2.2 \\
$2.8 \mathrm{~K} / \mathrm{NaY}$ & 536 & 437 & 2 & 1.6 \\
$3.5 \mathrm{~K} / \mathrm{NaY}$ & 124 & 43 & 1 & 0.3 \\
\hline
\end{tabular}

Table 7. Basic properties of K/NaY zeolites (Si/Al: 2.5) determined by TPD-CO ${ }_{2}$ [109]

\begin{tabular}{|c|c|c|c|c|}
\hline \multirow[b]{2}{*}{ Catalysts } & \multicolumn{3}{|c|}{$\begin{array}{l}\text { Quantity of basic sites } \\
\left(\mu \mathrm{mol}^{*} \mathrm{~g}^{-1}\right)\end{array}$} & \multirow[t]{2}{*}{$\begin{array}{l}\text { Density of basic } \\
\text { sites }\left(\mu \mathrm{mol}^{*} \mathrm{~m}^{-2}\right)\end{array}$} \\
\hline & $\begin{array}{l}\text { W } \\
(75- \\
175 \\
\left.{ }^{\circ} \mathrm{C}\right)\end{array}$ & $\begin{array}{l}M \\
(175 \\
\left.275^{\circ} \mathrm{C}\right)\end{array}$ & $\begin{array}{l}S \\
(275- \\
\left.375^{\circ} \mathrm{C}\right)\end{array}$ & \\
\hline $\mathrm{NaY}$ & 30 & 38 & 29.2 & 0.14 \\
\hline $0.35 \mathrm{~K} / \mathrm{NaY}$ & 11.5 & 39.1 & 28.1 & 0.11 \\
\hline $0.7 \mathrm{~K} / \mathrm{NaY}$ & 11.7 & 36.4 & 25.3 & 0.11 \\
\hline $1.4 \mathrm{~K} / \mathrm{NaY}$ & 21.3 & 35.4 & 22 & 0.12 \\
\hline $2.1 \mathrm{~K} / \mathrm{NaY}$ & 22.1 & 37.6 & 16.9 & 0.12 \\
\hline $2.8 \mathrm{~K} / \mathrm{NaY}$ & 28 & 37.5 & 15.7 & 0.14 \\
\hline $3.5 \mathrm{~K} / \mathrm{NaY}$ & 27 & 26 & 8.9 & 0.12 \\
\hline
\end{tabular}

On the basis of these initial analyses, it can be concluded that if $2.8 \mathrm{~K} / \mathrm{NaY}$ is the best catalyst, it is undoubtedly because it is a good "compromise" or equilibrium between acid and basic sites. With the addition of potassium, strong acid sites disappear almost completely, while the quantity of weak basic sites decreases at first then increases again. On the other hand, the quantity of strong basic sites decreases significantly. The catalyst preserves a sufficient number of weak and moderate acid sites and acquires mainly weak and moderate basic sites, while losing its strong sites. Over zeolites impregnated with halides, the 
conclusions are basically the same: $\mathrm{KI} / \mathrm{NaY}$ is the sample with the lowest density in acid sites $\left(2 \mu \mathrm{mol} . \mathrm{g}^{-1}\right)$, associated with a higher density in basic sites $\left(0.38 \mu \mathrm{mol} . \mathrm{g}^{-1}\right)$ [110]. XPS analyses of zeolites showed a gradual decrease of binding energy at level $O$ 1s. It can be interpreted as an increase in the electronic density of oxygens in the crystal structure $\left(\mathrm{O}^{2-}\right)$ and therefore in its basicity [110]. In presence of $\mathrm{K}^{+}$, which is very electropositive, binding energy decreases (Si 2p, Al 2p, O 1s), while in presence of an electronegative element the opposite effect is produced. This would explain why the best result is obtained with iodide (the least electronegative of halogens), which completes the action of $\mathrm{K}^{+}$.

On the basis of all these assumptions, the authors proposed the mechanism illustrated in Figure 9. This one-step elimination mechanism (type E2) coincides with the mechanism postulated by Gunter et al. for the dehydration of lactic acid to acrylic acid over supported phosphate-based catalysts with the formation of a C2 - C3 transition state (Figure 9) [110].

Therefore, it is easy to understand that to obtain an active and selective catalyst, the catalyst's acid and basic properties must be finely adjusted without neglecting its textural properties. Indeed, coking causes a more or less longterm drop in acrylic acid selectivity. Proper dosage of acid and basic properties enables lactic acid to adsorb without polymerizing and acrylic acid to then desorb following dehydration.

Figure 9. Mechanism proposed by Huang et al. for the dehydration of lactic acid to acrylic acid over KX-modified NaY zeolites. Reprinted with permission from [110].

Huang team continued its research with alkaline earth metals $(\mathrm{Ca}, \mathrm{Mg}, \mathrm{Sr}$ et $\mathrm{Ba}$ ). They obtain their best yield to acrylic acid of $44.6 \%$ with the $2 \% \mathrm{Ba} / \mathrm{NaY}$ catalyst $(\mathrm{Si} / \mathrm{Al}=4.5)$ [113]. They come to the same conclusions and attribute the catalyst good performance to the decrease in number and strength of acid sites, to the generation of weak and moderate basic sites and to the limited presence of strong basic sites. They describe the catalytic site as a cluster formed between the cation and 3 oxygen atoms of the sstructure, as represented in Figure 10 [113]:

Figure 10. Representation of clusters formed by alkali $\left(\mathrm{X}^{+}\right)$and alkaline earth metals $\left(\mathrm{X}^{2+}\right)$ and oxygens in the crystal structure of $\mathrm{NaY}$ zeolites. Reprinted with permission from [113]. 
$\mathrm{NaY}$ zeolites modified by alkali and alkaline earth metals and especially potassium have been shown to be good catalysts for the dehydration of lactic acid to acrylic acid. Although conversion is high (almost 100\%) and stable over time, acrylic acid selectivity decreases quite quickly. These performances are attributed to the interaction between cations and oxygens of the crystal structure, modulating acid and basic properties of zeolite in terms of site number and strength. Another observation is that a significant proportion of the products formed during the reaction are neither identified nor quantified. This explains well the complexity of this reaction, as the reagent and the product are likely to polymerise or form coke on the surface of the catalyst.

\subsection{Dehydration reaction over phosphate based catalysts}

From the work of Holmen onwards [87], phosphates had been identified as effective catalysts for the dehydration of $\mathrm{ML}$ and lactic acid $\left[\mathrm{NaH}_{2} \mathrm{PO}_{4}\right.$, $\mathrm{Ba}_{3}\left(\mathrm{PO}_{4}\right)_{2}, \mathrm{Na}_{4} \mathrm{P}_{2} \mathrm{O}_{7}$ (mixed with $\left.\mathrm{CaSO}_{4}\right), \mathrm{Zn}_{3}\left(\mathrm{PO}_{4}\right)_{2}, \mathrm{Na}_{2} \mathrm{PO}_{4} / \mathrm{SiO}_{2}$ ]. Although yields are below those obtained with the calcium and sodium mixed sulfates based catalyst some are quite high all the same. This is the case with barium phosphate, with which a yield of $50.7 \%$ of acrylic acid is obtained from lactic acid. Following these results, the teams of Sawicki [115] and Paparizos [116] were granted two patents in 1988 on the dehydration of lactic acid and ammonium lactate to acrylic acid and acrylate respectively. Paparizos et al. used aluminium phosphate $\left(\mathrm{AIPO}_{4}\right)$ treated in situ before the reaction with a 14 wt\% ammonia solution. Using $20 \mathrm{~cm}^{3}$ of catalyst, they obtained a yield to acrylic acid from lactic acid of $43.3 \%$ versus $61.1 \%$ from ammonium lactate. The difference between the two reagents can be explained by the ease with which lactic acid forms acetaldehyde $(34.7 \%$ selectivity to acetaldehyde from lactic acid versus $11.9 \%$ from ammonium lactate) [116]. On the basis of the conclusions concerning acid and basic properties of zeolites, it can assume that ammonia neutralises strong acid sites and should reduce acetaldehyde selectivity at the same time. At the reaction temperature $\left(340^{\circ} \mathrm{C}\right)$, ammonia desorbs from weak and moderate sites, leaving these sites available. However, the authors also tested the reaction of lactic acid under the same conditions without prior pre-treatment of phosphate. At almost equal conversion rate $(\approx$ $100 \%$ ), acrylic acid selectivity decreases (20.6\%) like that of acetaldehyde, which drops to $22.7 \%$ to the benefit of propionic acid that becomes the main product at $23.4 \%$. Therefore, it is difficult to explain why, in presence of ammonia, acetaldehyde selectivity increases. The authors also tested the neutralisation of strong sites by immersing the aluminium phosphate in a $\mathrm{KOH}$ (5wt\%) solution. They also note an improvement, certainly less significant than with ammonia, in acrylic acid selectivity that then increases from $20.6 \%$ to $32.1 \%$. On the other hand, this time acetaldehyde selectivity drops, conforming with observations made on potassium-impregnated zeolites. In parallel, Sawicki uses various phosphates (sodium, potassium, lithium and calcium hydrogeno- 
and dihydrogenophoshates; lanthanum and magnesium phosphates) supported over metal oxides $\left(\mathrm{SiO}_{2}, \mathrm{TiO}_{2}, \mathrm{Al}_{2} \mathrm{O}_{3}\right)$, postsynthesis-treated by bases such as sodium and potassium bicarbonate or sodium, potassium, lithium, calcium, magnesium and lanthanum carbonates. The best performances were obtained with sodium bicarbonate and silica as support previously impregnated with sodium dihydrogenophosphate. Here again, the authors attribute the best performances (a $58 \%$ yield to acrylic acid with $89 \%$ conversion of lactic acid) to the neutralisation of acid sites and the appearance of new sites favourable for dehydration. However, acetaldehyde selectivity remains relatively high. The authors do not provide much information on mass balances, carbon or byproducts, which makes a clear interpretation of the results difficult. Lastly, Gunter et al. study the conversion of lactic acid on phosphates and the formation of acrylic acid and 2,3-pentanedione [117]. Phosphates are already known as catalysts for the dehydration of alcohol and the authors suggest that high acrylic acid selectivities may be due to a stabilisation of the carboxylic group by phosphate groups, limiting thereby the formation of acetaldehyde [118]. Using infrared analyses (FTIR) and RMN ( $\left.{ }^{31} \mathrm{P}-\mathrm{RMN}\right)$, these authors have studied the interaction between lactic acid and different species of sodium phosphates [ $\left(\mathrm{NaPO}_{3}\right) n, \mathrm{NaH}_{2} \mathrm{PO}_{4}, \mathrm{Na}_{3} \mathrm{P}_{3} \mathrm{O}_{9}, \mathrm{Na}_{2} \mathrm{HPO}_{4}, \mathrm{Na}_{3} \mathrm{PO}_{4}$ and $\mathrm{Na}_{4} \mathrm{P}_{2} \mathrm{O}_{7}$ ]. By means of post-reaction infrared study, they observed the condensation of $\mathrm{Na}_{2} \mathrm{HPO}_{4}$ to $\mathrm{Na}_{4} \mathrm{P}_{2} \mathrm{O}_{7}$ that then exchanges a proton with lactic acid giving rise to the formation of a sodium lactate $\left(\mathrm{Na}_{3} \mathrm{HP}_{2} \mathrm{O}_{7}+\right.$ sodium lactate). Likewise, $\mathrm{Na}_{3} \mathrm{PO}_{4}$ can accept a proton of lactic acid to form $\mathrm{Na}_{2} \mathrm{HPO}_{4}$ that condenses again to $\mathrm{Na}_{4} \mathrm{P}_{2} \mathrm{O}_{7}$. These are precisely the species $\mathrm{Na}_{2} \mathrm{HPO}_{4}$ and $\mathrm{Na}_{3} \mathrm{PO}_{4}$ that are the most selective to acrylic acid. The authors also prove that the formation of lactate is an essential step without however succeeding in determining if sodium lactate is a reaction intermediate or if it plays the role of active site. Moreover, these results are coherent with those of Wadley et al. [90] that postulate the formation of a liquid layer on the surface of a silica-supported sodium nitrate-based catalyst. Here too, the authors identify the formation of sodium lactate and assume that this will be the species that plays the role of catalytic site. They also conclude that during important formations of acrylic acid, secondary reaction can become an important source of coking. Zhang et al. obtain a yield to acrylic acid and MA of $52 \%$ (approximately $50 \%$ of each species) from $\mathrm{ML}$ over the catalyst $\mathrm{NaH}_{2} \mathrm{PO}_{4} / \mathrm{SiO}_{2}$ (80:20) [119]. The importance of the support (other than dispersion) is not really obvious, especially since when it is partially uncovered, silica is not very selective to acrylic acid or acrylate. Silica has also been used by Lee et al. for supported tricalcium phosphate-based catalysts [120]. Here again, the ideal mass ratio is $\mathrm{Ca}_{3}\left(\mathrm{PO}_{4}\right)_{2} / \mathrm{SiO}_{2}$ (80: 20). If selectivities are more important, it is undoubtedly because the silica support is actually prepared with sodium silicate. On the other hand, yields do not exceed $60 \%$, because, at low temperatures $\left(350^{\circ} \mathrm{C}\right)$, conversion remains quite limited (64.3\%). By increasing the temperature, we gain of course in conversion but lose in selectivity at the same time. It is 
interesting to note that acrylic acid selectivity is much higher than MA selectivity. Here too, the authors conclude that this catalyst functions better than others, thanks to a high specific surface, adequate porosity and appropriate acid and basic properties. On the other hand, research conducted by Zhang et al. (another research team than the one mentioned above) is interesting, because they used zeolites as support for sodium hydrogenophosphate [121]. In their first work on commercial phosphate impregnated zeolite, they came to the usual conclusions on the basis of the results of FTIR and RMN analysis of ${ }^{31} \mathrm{P}$ : in situ formation of sodium lactate, adequate acid and basic properties (TPD of $\mathrm{NH}_{3}$ and $\mathrm{CO}_{2}$ ). By studying the influence of phosphate impregnation rates on conversion and selectivities, one can see that strong acid sites disappear, sites responsible for the conversion of lactic acid to acetaldehyde. By increasing the impregnation rate, we gain in acrylic acid selectivity but lose in conversion, as well as in acetaldehyde selectivity [122]. On the other hand, they faced the phenomenon of deactivation already noted by Huang et al. [111] and studied the regeneration of the catalyst, as presented in Figure 11, where the conversion of lactic acid $(\boldsymbol{\bullet})$ and selectivity to acrylic acid $(\bullet)$ are presented over time.

Figure 11. Assessment of the stability of the catalyst and its regeneration in air [122]: (a) first test carried out with fresh $14 \% \mathrm{NaH}_{2} \mathrm{PO}_{4} / \mathrm{NaY}$ for $28 \mathrm{~h}$, (b) second $8 \mathrm{~h}$ test carried out with the used catalyst. Reprinted with persmission from [122].

It can be seen that not only almost identical conversion after regeneration can be reached, but selectivity also remains at values that are much higher than those obtained with an equivalent time in the first test. If we compare it to a TOS of $8 \mathrm{~h}$, selectivity to acrylic acid initially at $52 \%$ increases to about $64 \%$. Without more data, it is difficult to draw conclusions, but an elimination of polymerised surface species and an improvement in the dispersion of phosphates and lactate-phosphate interactions can be assumed. The maximum yield to acrylic acid is $58 \%$, which is still less than $\mathrm{KI} / \mathrm{NaY}(68 \%)$ performances[110]. In order to limit deposits and other polymerisation in the microstructure of zeolites, the authors prepared the same catalyst, but this time using nanocrystalline zeolites. They obtain the results presented in Table 8 [123].

Table 8: Results of tests on catalytic dehydration of lactic acid over sodium phosphate-based catalysts supported on zeolite nanocrystals [123]

Catalysts Conv. Select. AA Yield (\%)

(\%) (\%)

\begin{tabular}{llll}
\hline AA & AC & $2,3 \mathrm{P}$ & PA
\end{tabular}




\begin{tabular}{|c|c|c|c|c|c|c|}
\hline $\mathrm{NaY}_{\text {com }}$ & 95.5 & 37.2 & 35.5 & 22 & 3.1 & 1.6 \\
\hline $\mathrm{NaY}-13.8^{*}$ & 89.6 & 43.4 & 38.9 & 37.7 & 3 & 0.8 \\
\hline $\mathrm{NaY}-16.9$ & 88.9 & 46.2 & 41.1 & 19.9 & 3.1 & 1.3 \\
\hline $\mathrm{NaY}-20.1$ & 91.6 & 45.9 & 42 & 13.6 & 2.5 & 1.1 \\
\hline $\mathrm{NaY}-26.3$ & 86.2 & 39.5 & 34 & 18.4 & 2.4 & 1.6 \\
\hline $\begin{array}{l}\mathrm{Na} 2 \mathrm{HPO} 4 / \mathrm{NaY} \\
\text { com }\end{array}$ & 82.3 & 65.7 & 54 & 4.6 & 4.6 & 1 \\
\hline $\begin{array}{l}\mathrm{Na}_{2} \mathrm{HPO}_{4} / \mathrm{NaY}- \\
13.8\end{array}$ & 92.3 & 76.8 & 70.9 & 4.8 & 5.3 & 1.1 \\
\hline $\begin{array}{l}\mathrm{Na}_{2} \mathrm{HPO}_{4} / \mathrm{NaY}- \\
16.9\end{array}$ & 94.6 & 75.4 & 71.3 & 3.8 & 5 & 1.1 \\
\hline $\begin{array}{l}\mathrm{Na}_{2} \mathrm{HPO}_{4} / \mathrm{NaY}- \\
20.1\end{array}$ & 93.5 & 79.5 & 74.3 & 5.1 & 5.2 & 1 \\
\hline $\begin{array}{l}\mathrm{Na}_{2} \mathrm{HPO}_{4} / \mathrm{NaY}- \\
26.3\end{array}$ & 94.3 & 75 & 70.7 & 4.5 & 4.5 & 1 \\
\hline
\end{tabular}

These results clearly show that nanocrystals are better supports and that the maximum yield to acrylic acid of $74.3 \%\left(\mathrm{Na}_{2} \mathrm{HPO}_{4} / \mathrm{NaY}-20.1\right)$ is much higher than that obtained with $\mathrm{Na}_{2} \mathrm{HPO}_{4} / \mathrm{NaYcom}(65.7 \%)$ or with previous supports $(58 \%)$ [122]. The authors attribute these variances to an incomplete zeolite structure, limiting the formation of tunnels in which deposits are produced, even if diffractograms obtained by XRD show the characteristic peaks of zeolites. Textural parameters have also been determined by adsorption/desorption of $\mathrm{N}_{2}$ and the external surface/BET surface ratio increases at the same time as the BET surface decreases. The authors claim the highest yield and productivity of acrylic acid $\left(12 \mathrm{mmol} . \mathrm{g}^{-1} \cdot \mathrm{h}^{-1}\right)$, nearly 4 times more than that reported by Peng et al. [124]. It is worth to note the gradual deactivation and a drop in yield to $44 \%$ in $10 \mathrm{~h}$ and the same beneficial effect obtained in regeneration of the catalyst as that commented above. $\mathrm{Li}$ et al. also proposed a catalyst made with a mesoporous MCM-41 silica as support for a blend of potassium hydrogenophosphate and aluminium sulphate [125]. By calcining at a high temperature $\left(550^{\circ} \mathrm{C}\right)$, a blend of aluminium phosphate $\left(\mathrm{AlPO}_{4}\right)$ and potassium sulphate $\left(\mathrm{K}_{2} \mathrm{SO}_{4}\right)$ is formed when phosphate is deposited first on the support. Strong acid sites are eliminated while weak sites are preserved. The authors attribute the good performance of their catalyst to the higher ratio of $\mathrm{B} / \mathrm{L}$ (Brønsted/Lewis) acid sites. This fact seems to be in contradiction with all observations generally made on zeolite-based catalysts and in particular by 
Zhang et al. on their nanocrystalline zeolite supports [123]. Recently, Blanco et al. published a thorough analysis of the reactivity of alkaline earth phosphates and interpreted their results by correlating acrylic acid selectivity and the acid base equilibrium [126]. The best selectivity is obtained for a 1:1 ratio, in terms of number of acid and basic sites, which supports the assumption of the acid-base association for the formation of acrylic acid. The best conversion is obtained on calcium hydroxyapatites (the highest specific surface), while the highest acrylic acid selectivity is obtained on barium phosphate (weak specific surface). The specific surface is undoubtedly an important parameter to prevent secondary reactions. Also recently published, the patent of Lingoes et al. for Procter \& Gamble contains remarkable results for catalysis, as well as aspects rarely addressed by previous research, in particular regarding operating conditions and the process [127]. The authors use mixtures of precipitated phosphates in presence of phosphoric acid by evaporation of the solution. They obtain mixtures of extremely low specific surfaces $\left(<1 \mathrm{~m}^{2}\right)$. The authors report excellent catalytic performances with a mixture of potassium phosphate and barium (K:Ba=40:60). They prepared two batches of it $(A$ and $B)$ and obtained the best reported acrylic acid selectivities of $92 \%(B)$ and $93 \%(A)$, with for sample A a $91 \%$ conversion of lactic acid and a $77 \%$ conversion for sample $B$. The $85 \%$ yield to acrylic acid obtained with catalyst $A$ far exceeds performances reported until then, all catalysts taken together. According to the authors, these performances are more or less maintained for at least $21.6 \mathrm{~h}$. However, the authors also confessed their inability to obtain results that can be reproduced, because between the two samples $A$ and $B$, the conversion varies from 91 to $77 \%$, or a difference of 14 points. Moreover, the values reported for the density of basic sites appear very significant, sometimes from 2 to 6 times greater than the values found on zeolites [128] and phosphates [129]. Of course, they perform low-temperature $\mathrm{CO}_{2}$ adsorption $\left(40^{\circ} \mathrm{C}\right)$ but it does not justify such differences that do not appear very realistic.

Barium phosphate also attracts the attention of Tang et al. who reported after the Lingoes patent [127] a yield to acrylic acid of $76 \%$ from lactic acid using barium pyrophosphate [130]. There is a fairly significant difference compared to the results obtained by Blanco et al. [126] However, reaction conditions are quite different, with a very low carrier gas and liquid flow rate (Gas: $1 \mathrm{~mL} \cdot \mathrm{min}^{-1}$ and Liquid: $1 \mathrm{~mL} \cdot \mathrm{h}^{-1}$ ) and a reaction temperature of $400^{\circ} \mathrm{C}$. Performances are relatively stable, but conversion and selectivity finally drop, as shown in Figure 12.

Figure 12. Stability over time of barium pyrophosphate during the dehydration of lactic acid to acrylic acid. Reprinted with permission from [130]. 
Among all unsupported phosphate-based catalysts, results obtained by Lingoes et al. [127] are far better than those reported by other categories of catalysts. Performances obtained with barium phosphates are very good, which distinguish these solids as a very promising way of obtaining high acrylic acid selectivities. However it should work at low temperature to prevent the formation of acetaldehyde. It is worth to be noticed that the specific surfaces of this category of catalysts are very low, which can limit or delay deactivation by polymersiation on the catalyst surface. Indeed, the low specific surface area assumes a very low or even inexistent porosity.

\subsection{Dehydration reaction over hydroxyapatites}

Hydroxyapatites (HAP) are a separate class of solids among phosphates, because of their structure and their versatility of composition. Main component of bones and teeth, this material has long been studied in the field of medicine. These solids have rapidly become a subject of study due to their application in basic or bi-functional catalysis, particularly the synthesis of heavy alcohols by the Guerbet reaction [131], Knoevenagel condensation reaction [132], Michael reaction [133], or for dehydration [134], oxidation [135] or dehyrogenation [136] reactions. This material has also long been studied in the field of medicine for applications such as bone integration [137], dental implants [138], or vectorisation of medicines [139]. HAPs have the general chemical formula $\mathrm{Ca}_{5}\left(\mathrm{PO}_{4}\right)_{3} \mathrm{OH}$, but are usually described with the formula $\mathrm{Ca}_{10}\left(\mathrm{PO}_{4}\right)_{6}(\mathrm{OH})_{2}$ that actually represents the two molecules in the crystal structure (crystal symmetry, spatial group 6/m), represented in Figure 13 [140].

Figure 13. Representation in directions $a, b$ and $z$ of the hexagonal structure of hydroxyapatite. Adapted from [140].

Within the structure, calcium atoms occupy two distinct types of sites, which we will call $\mathrm{Ca}(\mathrm{I})$ and $\mathrm{Ca}$ (II). For more clarity, a projection (ab) of the structure is represented in Figure 14 [141].

Figure 14. Projection ab of the hydroxyapatite structure. Adapted from [141].

The composition of hydroxyapatites is extremely variable, because not only are they rarely stoichiometric $(\mathrm{Ca} / \mathrm{P}=1.67)$, but each constituent element can also be, to a certain extent, substituted without losing the crystal structure[142]. $\mathrm{Ca}^{2+}$ ions can be replaced by mono- and di-valent cations. Depending on the size 
and valency of the constituent element, we can achieve up to $100 \%$ substitution. In literature, we describe the substitution of $\mathrm{Ca}^{2+}$ by $\mathrm{Sr}^{2+}, \mathrm{Ba}^{+}, \mathrm{Pb}^{2+}$, $\mathrm{Mg}^{2+}, \mathrm{Zn}^{2+}$ and $\mathrm{Na}^{+}$. The $\mathrm{PO}_{4}{ }^{3-}$ can be substituted by $\mathrm{CO}_{3}{ }^{2-}, \mathrm{AsO}_{4}{ }^{3-}, \mathrm{SiO}_{4}{ }^{4-}$, $\mathrm{VO}_{4}{ }^{3-}, \mathrm{SO}_{4}{ }^{2-}$ and $\mathrm{HPO}_{4}{ }^{2-}$. Moreover, apatites naturally contain carbonates on the surface and in the core of the solid in low proportions. The $\mathrm{OH}$ can be replaced by halogens: $\mathrm{F}^{-}, \mathrm{Cl}^{-}, \mathrm{Br}^{-}, \mathrm{I}^{-}$or $\mathrm{CO}_{3}{ }^{2-}$. As carbonates can replace $\mathrm{OH}$ and $\mathrm{PO}_{4}{ }^{3-}$, in the first case we will speak of type $A$ carbonates and in the second, type $B$ carbonates. Of course, we can find type $A, B$ or $A B$. hydroxyapatites. These substitutions accompany large variations in composition permitted in the natural composition of hydroxyapatites with excess or lack of calcium. This variation around the stoichiometric ratio $\left[\mathrm{Ca}_{10}\left(\mathrm{PO}_{4}\right)_{6}(\mathrm{OH})_{2}, \mathrm{Ca} / \mathrm{P}=1.67\right]$, enables a distinction to be made between the three types of hydroxyapatites:

= Deficient HAPs (sub-stoichiometry) $(1.5<\mathrm{Ca} / \mathrm{P}<1.67)$ : these HAPs lack calcium. Generally, the charge defect engendered is compensated by the generation of $\mathrm{HPO}_{4}{ }^{2-}$, a lower negative charge than that of $\mathrm{PO}_{4}{ }^{3}$ and by the loss of $\mathrm{OH}^{-}$bringing about the creation of a vacancy. We can then describe this system according to the formula: $\mathrm{Ca}_{10-x}\left(\mathrm{PO}_{4}\right)_{6-x}\left(\mathrm{HPO}_{4}\right)_{x}(\mathrm{OH})_{2-x}$, with $0<x \leq 1$ [143]. We will call these deficient hydroxyapatites HAP-Ds.

= $\quad$ Stoichiometric hydroxyapatites: with the formula $\mathrm{Ca}_{10}\left(\mathrm{PO}_{4}\right)_{6}(\mathrm{OH})_{2}$ that we will call HAP-S.

- $\quad$ The excess hydroxyapatites (over-stoichiometry): much less described in literature, excess $\mathrm{Ca}^{2+}$ is generally explained in the case of type $\mathrm{B}$ HAPs, in which phosphates are substituted with $\mathrm{CO}_{3}{ }^{2-}$. We can then describe this system according to the formula: $\mathrm{Ca}_{10}\left(\mathrm{PO}_{4}\right)_{6-x}\left(\mathrm{CO}_{3}{ }^{2-}\right.$ )$_{x}(\mathrm{OH})_{2-x}$, with $0<x \leq 1$ [144]. Over-stoichiometry can also be explained by the presence of an amorphous or crystalline layer of calcium on the surface, generated during synthesis [142]. We will call these hydroxyapatites HAP-Es.

These variations in composition have a very strong impact on the acid and basic properties of solids. In the case of HAP-Ds, calcium deficiency causes a drop in basicity [145] and an increase of acidity [146]. In the case of HAP-Es, an increase of basicity [147] and a drop in acidity [144] could be generally observed. All these variations mainly concern site density, but a similar variation in site strength to a lesser extent can be also observed. These materials have already received the attention of two research teams, Matsuura et al. [148] and Umbarkar et al. [149] for the dehydration of lactic acid. Matsuura et al. have studied the impact of the variation of the $\mathrm{Ca} / \mathrm{P}$ ratio associated with the partial substitution of calcium by sodium [146], as well as the effect of the substitution of calcium by $\mathrm{Pb}$ or $\mathrm{Sr}$ and $\mathrm{P}$ by $\mathrm{V}$ [150] for HAPs prepared by hydrothermal synthesis. The authors obtains excellent yields (in the order of $70 \%$ ) of acrylic acid with the catalyst $\mathrm{Ca}-\mathrm{Na}-\mathrm{HAP}(1.55)(\mathrm{Ca} / \mathrm{P}=1.55 ;(\mathrm{Ca}+\mathrm{Na}) / \mathrm{P}=1.65)$, with a remarkable stability over time, as presented in Figure 15. 
Figure 15. Stability over time of the catalyst Ca-Na-HAP(1.55) during the reaction of dehydration of lactic acid to acrylic acid. Reprinted with permission from [146].

It can be seen that they obtain similar results with a HAP-S in the patent filed before the academic publication [151]. It would be interesting to understand why catalysts with different compositions and properties are not distinguishable during catalytic tests, as is however the case with the different catalysts tested in their publication [146]. It is unfortunate that the reference HAP-S of the publication concerning Ca-Na-HAP(1.55) is a commercial HAP (HAP-300, Taihei Chemical). Moreover, during the study on the substitution of $\mathrm{Ca}$ by $\mathrm{Sr}$, Sr-HAP presents better results than Ca-HAP with a yield to acrylic acid of $45 \%$ versus $38 \%$. Matsuura et al. conclude like Blanco et al. [126] that it is the excellent equilibrium of acid/base (A/B) sites with relatively moderate strengths and the absence of strong sites that give their catalyst a higher performance level. On the other hand, Umbarkar et al. come to very different conclusions. The first patent they filed shows very good performances for a catalyst (reference NaHAP-3b) undoubtedly very close in composition to Ca-NaHAP(1.55), but prepared by co-precipitation. The patent reports a total conversion associated with a $70 \%$ selectivity to acrylic acid [152]. However, this team focuses on generating acidity on HAPs by tuning the value of the $\mathrm{Ca} / \mathrm{P}$ ratio, as published subsequently with a catalyst presented as an HAP with a theoretical ratio $\mathrm{Ca} / \mathrm{P}=1.3$ [152]. For more clarity, the different calcium phosphates phases obtained according to the $\mathrm{Ca} / \mathrm{P}$ ratio are presented in Table 9 [142].

Table 9: Different calcium phosphate phases and corresponding $\mathrm{Ca} / \mathrm{P}$ ratios [142]

\begin{tabular}{|l|l|l|}
\hline Name & Molecular formula & Ca/P ratio \\
\hline $\begin{array}{l}\text { Octacalcium } \\
\text { phosphate }\end{array}$ & $\mathrm{Ca}_{8} \mathrm{H}_{\left(\mathrm{PO}_{4}\right)_{6}, 5 \mathrm{H}_{2} \mathrm{O}}$ & 1.33 \\
\hline $\begin{array}{l}\text { Dibasic calcium } \\
\text { phosphate }\end{array}$ & $\mathrm{Ca}\left(\mathrm{HPO}_{4}\right)_{2}, 2 \mathrm{H}_{2} \mathrm{O}$ & 1 \\
\hline $\begin{array}{l}\text { Tribasic calcium } \\
\text { phosphate }\end{array}$ & $\mathrm{Ca}_{3}\left(\mathrm{PO}_{4}\right)_{2}$ & 1.5 \\
\hline $\begin{array}{l}\text { Calcium } \\
\text { monophosphate }\end{array}$ & $\mathrm{Ca}\left(\mathrm{H}_{2} \mathrm{PO}_{4}\right)_{2}$ & 0.5 \\
\hline Stoichiometric & $\mathrm{Ca}_{10}\left(\mathrm{PO}_{4}\right)_{6}(\mathrm{OH})_{2}$ & 1.67 \\
\hline
\end{tabular}


hydroxyapatite

The authors proposed, drawing on infrared analyses (identification of lactate on the surface), two mechanisms, one for the formation of acrylic acid, the other for the formation of acetaldehyde, presented in Figure 16 [152].

Figure 16. Mechanisms proposed by Umbarkar et al. for the conversion of lactic acid to acrylic acid (a) and to acetaldehyde (b) over HAPs. Adapted from [152].

Even if the mechanisms are plausible, we should exercise caution because sites present on the surface on HAPs with such varied composition - with the very probable presence of other phases - are far from being identified and quantified. The last results presented by Umbarkar et al. on the study of the dehydration reaction of lactic acid were obtained on calcium phosphates prepared in the presence of sodium and the best results were obtained with a calcium phosphate prepared for a $\mathrm{Ca} / \mathrm{P}$ ratio of 0.76 . They obtain a $100 \%$ conversion and $78 \%$ selectivity, concluding this time that it is the good acidbase equilibriium of 11 that produces these results. Here again they obtain the highest A/B ratio [153]. Very recently, the team of Yan et al. studied an aspect not addressed by other teams, namely the effect of calcination temperature (from 360 to $700^{\circ} \mathrm{C}$ ) on the catalytic performance of HAPs. They also provided a detailed analysis of the evolution of these performances (conversion, acrylic acid and acetaldehyde selectivity, specific productivities) according to the $\mathrm{Ca} / \mathrm{P}$ ratio (from 1.58 to 1.69) and acid and basic properties[154]. They obtain their best yield to acrylic acid of $62 \%$ at $360^{\circ} \mathrm{C}\left(\mathrm{WHSV}: 1.4 \mathrm{~h}^{-1}\right)$ with a HAP $(\mathrm{Ca} / \mathrm{P}$ : 1.62) calcinated at $360^{\circ} \mathrm{C}$.

Phosphates are clearly an interesting route for the development of catalysts for the dehydration of lactic acid to acrylic acid in the gas phase. Selectivities to acrylic acid are above those reported for zeolites and phosphates appear to have better resistance to deactivation by formation of coke on their surface. Therefore, they are generally more stable under reaction flow and even appear more effective after a first regeneration. However, it appears relatively difficult to identify which are the preferable phases and which are active sites or mechanisms involved on these solids. The conclusions of the various research teams on this subject are sometimes contradictory. Lingoes et al. affirmed that their catalysts based on mixed barium and potassium phosphates owe their excellent performance to a particularly high density of basic sites, while Umbarkar et al. try to develop the acid properties of their solids. Lastly, Blanco et al., Tsuchida et al. and Yan et al. advocate an acid/base equilibrium. Literature is very recent, and it is undeniable that the scientific community lacks 
hindsight on this subject. Given the great diversity of materials in phosphates, much research remains to be done to clarify this situation.

\section{Conclusions:}

Benefiting from a literature that is already very rich, there has been a recently renewed interest for the study of the dehydration reaction of lactic acid, because it still remains a challenge to understand and control. Even today, all aspects of the reaction have not been addressed and we are just beginning to wonder about the influence of conditions under which the catalysts developed have been tested. The conception of these zeolite- or phosphate- or even sulphatebased catalysts must undoubtedly take into account the production upstream of lactic acid, if it is produced by chemical means. There is also the question of the properties desired. Although the dehydration reaction should be carried out on an acid site, we assume the participation of basic sites. Do they participate in the reaction mechanism? Do they influence the adsorption/desorption mechanisms of reaction species or products? Or is it a basic reaction mechanism, as suggested by Hammaecher et al .[155]? 


\section{Bio of the authors:}

1) Thomas Bonnotte

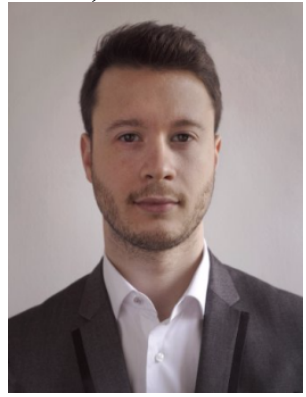

Dr. Thomas Bonnotte received his Paris Sorbonne's MD in Materials Chemistry at the University of Pierre \& Marie Curie (2011) then joined the UCCS laboratory of University Lille 1 for his PhD, received in 2015. He is currently postdoctoral researcher at the Ecole Centrale de Lille to study the ethanol valorization and still focus his research's interests on the design of catalytic materials applied to the biomass valorization.

2) Sebastien Paul

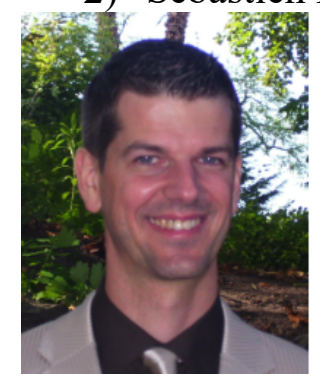

Prof Sébastien Paul is Full Professor at the Centrale Lille, a Generalist Engineer School in the North of France, where he was the head of the Sciences of the Matter department between 2009 and 2016. After his PhD in Chemical Engineering at the University of Technology of Compiègne, France (1996), he was hired by the Centrale Lille as an Assistant Professor (1998). In 2009 he was nominated Associate Professor and in 2011 Full Professor. His research work is carried out in the Unite de Catalyse et Chimie du Solide (UCCS - UMR CNRS 8181), France, which comprises more than 230 persons. More particularly he is the head of the VAALBIO group (standing for VAlorization of the ALkanes and of compounds issued from the BIOmass). Sébastien PAUL is also the coordinator of the REALCAT project ('Advanced HighThroughput Technologies Platform for Biorefineries Catalysts Design'). He is involved in the development of a large variety of catalytic processes starting from compounds issued from biomass or hydrocarbons in the frame of academic and industrial collaborations.

3) Marcia Araque-Marin 


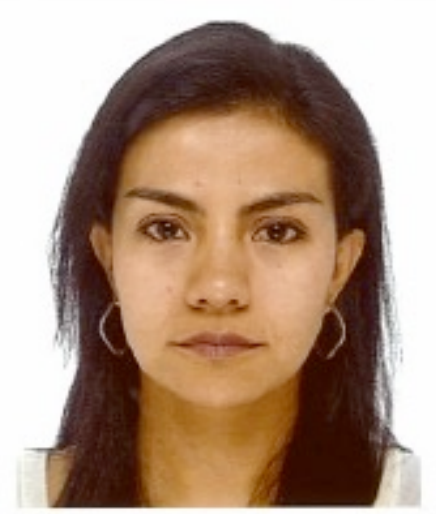

Dr Marcia Araque-Marin is an assistant Professor at Ecole Centrale de Lille and member of the UCCS laboratory (Unité de Catalyse et de Chimie du Solide) since 2012. In 2007, she obtained her Master degree in Chemical Engineering at the University of Colombia (Bogota) in cooperation with the Laboratoire des Matériaux, Surfaces et Procédés pour la Catalyse (LMSPC - UMR 7515). Following the Master degree, she continued the research within the frame of an international PhD program between Colombia and France on the valorization of glycerol in vapor phase using heterogeneous catalysts. Thus, in 2011, she obtained her PhD degree from the University of Strasbourg and the National University of Colombia. Her research is focused on use and development of high-throughput technologies for the synthesis and screening of catalysts, in the main topic of biomass valorization.

4) Robert Wojcieszak

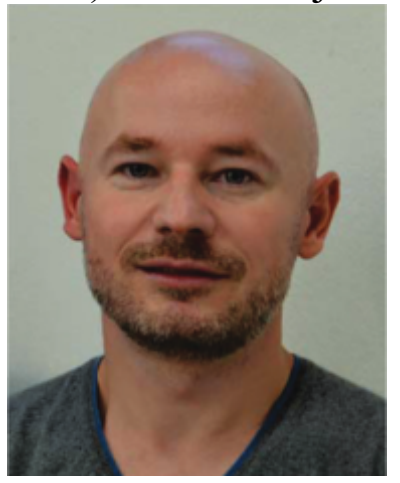

Dr Robert Wojcieszak received his Ph.D. in Physical Chemistry from the University of Lorraine in France in 2006. In 2008 he joined the IMCN at the Catholic University of Louvain in Belgium. In 2013 he was working on carbohydrate oxidation at the University of São Paulo in Brazil. Later that year he joined the UCCS team at the University of Lille in France, and he is currently a 1st class CNRS researcher. He is involved in the development of new advanced catalysts for biomass transformation using heterogeneous and hybrid catalysis. His research is focused especially on the oxidation, hydrogenation and amination of bio-based compounds and shape selectivity processes in heterogeneous catalysis.

5) Franck Dumeignil 


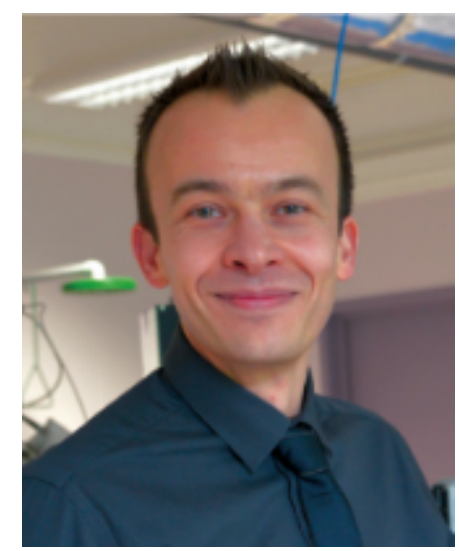

After obtaining his PhD in 1998 from Lille University, Franck Dumeignil spent six years in Japan: a post-doctoral stay of 2 years at the NIMC in Tsukuba before obtaining a 2-year postdoctoral contract at the Tokyo University of Agriculture and Technology (TUAT), following which he became Associate Professor at a Centre of Excellence (Scientific Cluster). He returned to France as a Full Professor at Lille University, Sciences and Technologies, where he piloted several research projects. In 2010, he was appointed Deputy Director, and then Director in 2016, of UCCS, UMR CNRS 8181, which employs more than 250 people. He coordinated the PCRD7 European EuroBioRef Programme 'EUROpean Multilevel Integrated BIOREFinery Design for Sustainable Biomass Processing' (www.eurobioref.org). End 2011, he was awarded the ANR EQUIPEX REALCAT project ('Advanced high throughput technologies platform for biorefineries catalysts design') and created the Franco-Japanese International Associate CNRS Laboratory CAT\&P4BIO ('Innovative Catalysts for Oxidation Reactions and Processes, Biomass Conversion') of which he is Director. Recently, he was nominated as responsible of the French Mirror of the Mixt International Unit ('UMI') number $3464 \mathrm{CNRS} /$ Solvay in Shanghai 'Eco-Efficient Products and Processes Laboratory' (E2P2L). He further received a few prices and awards, including a few scientific papers and congress presentation awards.

6) Benjamin Katryniok

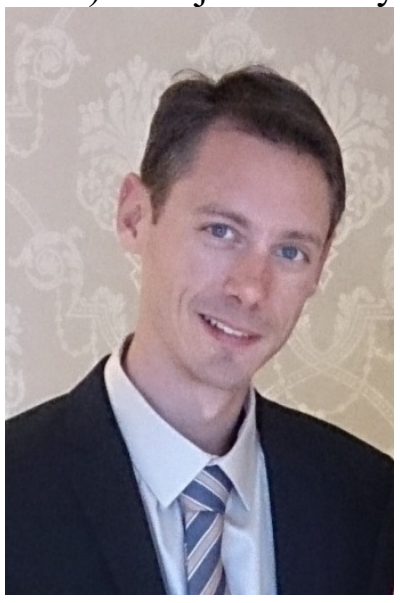

Dr Benjamin Katryniok is Associate Professor at Ecole Centrale de Lille (France) and researcher in the UCCS laboratory at Lille (France) since 2010. Graduated in Chemistry from the RWTH Aachen (Germany) in 2007, he obtained his PhD from Lille University (France) in 2010 for his 
work on glycerol catalytic dehydration, a work performed in collaboration with ADISSEO (Bluestar Company). Actually he is at the head of "Sciences of the Matter" Department at Ecole Centrale de Lille. His main research interest concerns the valorization of biomass derived platform molecules to value added intermediates. Thus he is one of the leading experts in the dehydration of glycerol to acrolein with 17 peer-reviewed articles and 5 patens. 


\section{References:}

[1] Process Economics Program Report 6E Acrylic acid from glycerin. A. Pavone, 2011, SRI Consulting, IHS Inc.

[2] From marketpublishers.com

[3] C.W. Scheele, O.Mjolk, Vetenskaps-Academiens nya Handlingar. Kgl., 1780, 1, 116-124.

[4] R.P. John, G.S.Anisha, K.M.Nampoothiri, A.Pandey. Biotech. Adv., 2009, 27(2), 145-152.

[5] R. Datta, S.-P.Tsai, P.Bonsignore, S.-H.Moon, J.R.Franck, FEMS Microbio. Rev. 1995, 16(2-3), 221-231.

[6] W. Groot, J.van Krielen, O.Sliekersl, S.de Vos, Production and Purification of Lactic Acid and Lactide, in Poly(Lactic Acid). 2010, John Wiley \& Sons, Inc. p. 1-18.

[7] F.A. Castillo Martinez, E.M.Balciunas, J.M.Salgado, J.M.Dominguez, A.Converti, R.P.de Souza Oliveira, Trends in Food Sci. \& Tech., 2013, 30(1), 70-83.

[8] W.A Beacham, Map updating the global bioplastics picture. 2012 [cited 2016; Available from: http://www.icis.com/Articles/2012/03/12/9539967/a-map-updating-the-global-bioplastics-

picture.html.

[9] M.A. Abdel-Rahman, Y.Tashiro, K.Sonomoto, J. Biotech. 2011, 156(4), 286-301.

[10] J. Redtenbacher, Ann. 1843, 47.

[11] T.Ohara, T.Sato, N.Shimizu, G.Prescher, H.Schwind, O.Weiberg, K.Marten, H.Greim, Acrylic Acid and Derivatives, in Ullmann's Encyclopedia of Industrial Chemistry. 2000, WileyVCH Verlag GmbH \& Co. KGaA.

[12] W. Bauer, Acrylic Acid and Derivatives, in Kirk-Othmer Encyclopedia of Chemical Technology. 2000, John Wiley \& Sons, Inc.

[13] C. Boswell, http://www.icis.com/Articles/2012/04/16/9549968/on-purpose-technologiesready-to-fill-propylene-gap.html. $2012 ; \quad$ Available http://www.icis.com/Articles/2012/04/16/9549968/on-purpose-technologies-ready-to-fillpropylene-gap.html.

[14] N. Wedle, http://www.icis.com/Articles/2014/09/25/9823932/EPCA-Olefins-evolution.html. 2014; Available from: http://www.icis.com/Articles/2014/09/25/9823932/EPCA-Olefinsevolution.html.

[15] C. Boswell, Acrylate prices drive new manufacturing routes. 2011; Available from: http://www.icis.com/resources/news/2011/06/10/9468586/acrylate-prices-drive-newmanufacturing-routes/.

[16] T. Mellor, http://www.icis.com/resources/news/2012/11/29/9619715/price-and-markettrends-europe-acrylates-players-seek-price-direction-from-december-propylene/. 2012.

[17] J. Dietrich, http://www.icis.com/globalassets/global/icis/pdfs/sample-reports/chemicalspropylene.pdf. 2014; Available from: http://www.icis.com/globalassets/global/icis/pdfs/samplereports/chemicals-propylene.pdf.

[18] L. Landress, http://www.icis.com/globalassets/global/icis/pdfs/sample-reports/chemicalsglycerine.pdf. 2014; Available from: http://www.icis.com/globalassets/global/icis/pdfs/samplereports/chemicals-glycerine.pdf.

[19] C.E. Avery, Manufacture of lactates. 1881 and 1885, Avery Lactate Company: United States.

[20] M.A. Paivi, I.Simakova, T.Salmi, D.Murzin, Chem. Rev. 2014, 114(3), 419-427

[21] G. Juodeikiene, D.Vidmantiene, L.Basinskiene, D.Cernauskas, E.Bartktiene, D. Cizeikiene, Catal. Today, 2015, 239, 11-16.

[22] M.A. Abdel-Rahman, Y.Tashiro, K. Sonomoto, Biotech. Adv., 2013, 31(6), 877-902.

[23] J.N. Starr, G. Westhoff, Lactic Acid, in Ullmann's Encyclopedia of Industrial Chemistry. 2000, Wiley-VCH Verlag GmbH \& Co. KGaA.

[24] Z.Y. Zhang, B. Jin, J.M. Kelly, Biochem. Eng. J., 2007, 35(3), 251-263.

[25] C.R. Soccol, B. Marin, M.Raimbault, J.M.Lebeault, Appl. Microbio. Biotech., 1994, 41(3), 286-290.

[26] D.-M.Bai, M.-Z.Jia, X.-M. Zhao, R.Ban, F.Shen, X.-G.Li, S.-M.Xu, Chem. Eng. Sci., 2003, 58(3-6), 785-791.

[27] M.Taskin, N. Esim, S. Ortucu, Food Bioprod. Process., 2012, 90(4), 773-779.

[28] E.Y.Park, P.N. Anh, N. Okuda, Biores. Tech., 2004, 93(1), 77-83.

[29] E.T.H.Vink, D.A.Glassner, J.J.Kolstad, R.J.Wooley, R.P.O'Connor, Ind. Biotech., 2007, 3(1), 58-81.

[30] T.Liu, S.Miura, M.Yaguchi, T.Arimura, E.Y.Park, M.Okabe, J. Biosci. Bioeng., 2006, 101(1), 9-12. 
[31] B.P.Calabia, Y.Tokiwa, S.Aiba, Biotech. Lett., 2011, 33(7), 1429-1433

[32] N.K. Budhavaram, Z. Fan, Biores. Tech., 2009, 100(23), 5966-5972.

[33] Y.Meng, Y.Xue, B.Yu, C.Gao, Y.Ma, Biores. Tech., 2012, 116(0), 334-339.

[34] S.Okino, M. Inui, H. Yukawa, Appl. Microbio. Biotech., 2005, 68(4), 475-480.

[35] M.Dusselier, P.Van Wouwe, A.Dewaele, E.Makshina, B.F.Sels, Ener. Environ. Sci., 2013, 6(5), 1415-1442.

[36] J.Eriksen, O.Mønsted, L.Mønsted, Trans. Met. Chem., 1998, 23(6), 783-787.

[37] C.B. Rasrendra, B.A.Fachri, I.G.B.N Makertihartha, S. Adisasmito, H.J.Heeres ChemSusChem, 2011, 4(6), 768-777.

[38] E.Taarning, S.Saravanamurugan, M.Spangsberg Holm, J.Xiong, R.M. West, C.H.Christensen, ChemSusChem, 2009, 2(7), 625-627.

[39] L.Li, C.Stroobants, K.Lin, P.A Jacobs, B.F Selfs, P.P Pescarmona., Green Chem., 2011. 13(5), 1175-1181.

[40] F.de Clippel, M.Dusselier, R.Van Rompaey, P.Vanelderen, J.Dijkmans, E. Makshina, L.Giebeler, S. Oswald, G.N.Baron, J.F.M.Denayer, P.P.Pescarmona, P.A. Jacobs, B.F.Sels, JACS, 2012, 134(24), 10089-10101.

[41] X.Jin, D.Roy, P.S.Thapa, B.Subramaniam, R.V.Shaudhari, ACS Sust. Chem. Eng., 2013, 1(11), 1453-1462.

[42] J.Dakka, H. Goris, Catal. Today, 2006, 117(1-3), 265-270.

[43] P.Hadik, L.-P. Szabó, E. Nagy, Desalination, 2002, 148(1-3), 193-198.

[44] P.Hadik, L.-P. Szabó, E.Nagy, Z.Farkas, J. Memb. Sci., 2005, 251(1-2), 223-232.

[45] A.Boonpan, S. Pivsaart, S.Pongswat, A.Areesirisuk, P. Sirisangsawang, Ener. Proced., 2013, 34(0), 898-904.

[46] S.Parida, J.S. Dordick, JACS, 1991, 113(6), 2253-2259.

[47] P.Van Wouwe, M.Dusselier, A.Basic, B.F.Sels, Green Chem., 2013, 15(10), 2817-2824.

[48] L.Tanya, Global Acrylic Acid Production to Reach 5.94 Mln Tonnes in 2017, According to In-demand Report by Merchant Research \& Consulting. 2014 23/12/2014]; Available from: http://www.prweb.com/releases/2014/02/prweb11597545.htm.

[49] BASF. 2014; Available from: http://www.basf.com/group/pressrelease/P-14-336.

[50] R.A. Sheldon, Green Chem., 2014. 16(3), 950-963.

[51] B.Thompson, T.S. Moon, D.R. Nielsen, Curr. Opi. Biotech., 2014, 30(0), 17-23.

[52] Biotechnologies, [cited 2012; Available from: http://www.opxbio.com/2012/09/thecommercialization-of-bioacrylic-acid/.

[53] M.Bomgardner, Chem. Eng. News Arch., 2011, 89(16), 9, ISSN 0009-2347

[54] R.D. Kuchta, R.H. Abeles, J. Bio. Chem., 1985. 260(24), 13181-13189.

[55] D.J.O'Brien, C.C. Panzer, W.P. Eisele, Biotech. Prog., 1990. 6(4), 237-242.

[56] R.K.A.M.C Dalal, C.L. Sinskey, A.J. Biosour. Digest, 1980. 2, 89-97.

[57] H.Danner, M.Ürmös, M.Gartner, R.Braun, Appl. Biochem. Biotech., 1998. 70-72(1), 887894.

[58] W.Luo, J. Cai, L. Zhu, X.Zhu, L.Huang, Z.Xu, P.Cen, Eng. Life Sci., 2012. 12(5), 567-573.

[59] A.J.Straathof, S.Sie, T.T.Franco, L.M.vn der Wielen, Appl. Microbio. Biotech., 2005. 67(6), 727-734.

[60] B.H.Lunelli, E.R.Duarte, E.C.Vasco de Toledo, M.R. Wolf Maciel, R. Maciel Filho, Appl. Biochem. Biotech., 2007. 137-140(1-12), 487-499.

[61] A.J.J., Straathof, Chem. Rev., 2013. 114(3), 1871-1908.

[62] G. Allen, Oxidation of unsaturated aldehydes to the corresponding acids. 1972, CELANESE CORP.: United States.

[63] G.T. Yamaguchi Shigeo, Production of unsaturated aliphatic acids. 1967, Nippon Kayaku CO. LTD.: United States.

[64] R.E. Krabetz, H.Engelbach, Production of acrylic acid by oxidation of acrolein. 1970, BASF, DT.

[65] A.Nakajima, N. Fukumoto, Process for producing acrylic acid. 2010, NIPPON SHOKUBAI CO., LTD.

[66] M.Tanimoto, Complex oxide catalyst and process for preparation of acrylic acid, E.P. Office, Editor. 2005, NIPPON SHOKUBAI CO., LTD OSAKA.

[67] J.L. Dubois, C. Duquenne, W. Hölderich, Procédé de préparation d'acide acrylique à partir de glycérol. 2008, Arkema.

[68] M.M.Okuno, E. Takahashi, T. Kasuga, Catalyst for glycerine dehydration and manifacturing method for acrolein. 2007, Nippon Catalytic Chem. Ind.: Japan. 
[69] L.G.Possato, R.N.Diniz, T.Garetto, S.H.Pulcinelli, C.V.Santilli, L.Martins, J. Catal., 2013. 300(0), 102-112.

[70] Y.T.Kim, K.-D.Jung, E.D.Park, Appl. Catal. A: Gen., 2011. 393(1-2), 275-287.

[71] B.Katryniok, S.Paul, M.Capron, V.Bellière-Baca, F.Dumeignil, ChemSusChem, 2012. 5(7), 1298-1306.

[72] B.Katryniok, S.Paul, V.Bellière-Baca, P.Rey, F. Dumeignil, Green Chem. 2010. 12(12), 2079-2098

[73] M.Okuno, E. Matsunami, T.Takahashi, H.Kasuga, Catalyst for glycerine dehydration and manifacturing method for acrolein, 2007, Nippon Catalytic Chem. Ind.: Japan.

[74] Y.T.Kim, K.-D.Jung, E.D.Park, Appl. Catal. A: Gen., 2011. 393(1-2), 275-287.

[75] A.S.de Oliveira, S.J.S.Vasconcelos, J.R. de Souza, F.F. de Souza, , J.Maciel Filho, A.C.Oliveira. Chem. Eng. J., 2011. 168(2), 765-774.

[76] B.Katryniok, S. Paul, F. Dumeignil, ACS Catalysis, 2013. 3(8), 1819-1834.

[77] M.N.Timofeeva, Appl. Catal. A: Gen., 2003. 256(1-2), 19-35.

[78] A.Martin, U. Armbruster, H. Atia, Euro. J. Lipid Sci. Tech., 2012. 114(1), 10-23.

[79] H.Atia, U.Armbruster, A., Martin, J. Catal., 2008. 258(1), 71-82.

[80] Y.T. Kim, K.S. Jung, E.D. Park, Bull. Korean Chem. Soc., 2010. 31, 3283-3290.

[81] H.Atia, U.Armbruster, A.Martin, Appl. Catal. A: Gen., 2011. 393(1-2), 331-339.

[82] E.Tsukuda, S.Sato, R.Takahashi, T.Sodesawa, Catal. Comm., 2007. 8(9), 1349-1353.

[83] S.-H. Chai, H.-P. Wang, Y. Liang, B.-Q. Xu, Green Chem., 2008. 10(10), 1087-1093.

[84] B.Katryniok, S.Paul, M. Capron, C. Lancelot, V. Bellière-Baca, P.Rey, F. Dumeignil. Green Chem., 2010. 12(11), 1922-1925.

[85] B.Katryniok, S.Paul, M.Capron, V.Bellière-Baca, F.Dumeignil, ChemSusChem, 2012. 5(7), 1298-1306.

[86] L.Shen, H.Yin, A.Wang, X.Lu, C.Zhang, Chem. Eng. J., 2014. 244(0), 168-177.

[87] R.E.Holmen, Production of acrylates by catalytic dehydration of lactic acid and alkyl lactates. 1958, MINNESOTA MINING \& MFG: United States.

[88] W.S.L.Mok, M.J.Antal, M.Jones, J. Org. Chem., 1989. 54(19), 4596-4602.

[89] R.Beerthuis, M.Granollers, D.R.Brown, H.J.Salvagione, G.Rothenberg, R.N.Shiju, RSC Adv., 2015, 5, 4103-4108.

[90] D.C.Wadley, M.S.Tam, P.B.Kokitkar, J.E.Jackson, D.J.Miller, J. Catal., 1997. 165(2), 162171.

[91] B.Katryniok, S. Paul, F. Dumeignil, Green Chem., 2010. 12(11), 1910-1913.

[92] T.M.Aida, A. Ikarashi, Y. Saito, M.Watanabe, R.L.J. Smith, K. Arai, J. Super. Fluids, 2009. 50(3), 257-264.

[93] D.T.Vu, A.K.Kolah, N.S.Asthana, L.Peereboom, C.T.Lira, D.J. Miller. Fluid Phase Equilibria, 2005, 236(1-2), 125-135.

[94] A.H.Takafumi, S.Hieda, Process for preparing unsaturated carboxylic acid or ester thereof, M.G.C. Compagny, Editor. 1993: Japan.

[95] D.Bougeard, K.S. Smirnov, PCCP, 2007. 9(2), 226-245.

[96] S.M.C Auerbach, P. K.Dutta, Handbook Of Zeolites Science and technology, in Handbook Of Zeolites Science and technology, S.M.C. Auerbach, K. A.; Dutta, P. K., Editor. 2003, CRC Press.

[97] S. Aldrich, Available from: http://www.sigmaaldrich.com/chemistry/chemicalsynthesis/learning-center/technical-bulletins/al-1430/molecular-sieves.html.

[98] R.P.K.Wells, P.Tynjälä, J.E. Bailie, D.J.Willock, G.W.Watson, F.King, C.H. Rochester, D.Bethell, P.C.Bulman Page, G.J.Hutchings, Appl. Catal. A: Gen., 1999. 182(1), 75-84.

[99] K.J. Balkus, A.K. Khanmamedova, J. Catal., 1995. 151(1), 10-16.

[100] P.Sun, D.Yu, K.Fu, M.Gu, Y.Wang, H.Huang, H.Ying, Catal. Comm., 2009. 10(9), 13451349.

[101] H.F.Shi, Y.C.Hu, Y.Wang, H.Huang. Chin. Chem. Lett., 2007. 18(4), 476-478.

[102] J.Yan, D.Yu, H.Li, P.Sun, H.Huang, J. Rare Earths, 2010. 28(5), 803-806.

[103] H.Wang, D.Yu, P.Sun, J.Yan, Y.Wang, H.Huang, Catal. Comm., 2008. 9(9), 1799-1803.

[104] P.Sun, D.Yu, K.Fu, M.Gu, Y.Wang, H.Huang, H.Ying, Catal. Comm., 2009. 10(9), 13451349.

[105] D.H.Olson, G.T. Kokotailo, J.F. Charnell, J. Coll. Inter. Sci., 1968. 28(2), 305-314.

[106] J.Yan, D.Yu, P.Sun, H.Huang, Chin. J. Catal., 2011. 32(3-4), 405-411.

[107] J.G.Nery, Y.P.Mascarenhas, T.J. Bonagamba, N.C.Mello, E.F.Souza-Aguiar. Zeolites, 1997. 18(1), 44-49.

[108] P.Sun, D.Yu, Z.Tang, H. Li, H.Huang Ind. Eng. Chem. Res., 2010. 49(19), 9082-9087. 
[109] P.Sun, D.Yu, K.Fu, M.Gu, Y.Wang, H.Huang, H.Ying, Catal. Comm., 2009. 10(9), 13451349.

[110] P.Sun, D.Yu, Z.Tang, H. Li, H.Huang Ind. Eng. Chem. Res., 2010. 49(19), 9082-9087.

[111] P.Sun, D.Yu, K.Fu, M.Gu, Y.Wang, H.Huang, H.Ying, Catal. Comm., 2009. 10(9), 13451349.

[112] G.C.Gunter, D.J.Miller, J.E.Jackson, J. Catal., 1994. 148(1), 252-260..

[113] J.Yan, D.Yu, P.Sun, H.Huang, Chin. J. Catal., 2011. 32(3-4), 405-411.

[114] R.C.Deka, R.Kinkar Roy, K.Hirao, Chem. Phys. Lett., 2000. 332(5-6), 576-582.

[115] R.A.Sawicki, Catalyst for dehydration of lactic acid to acrylic acid. 1988, Texaco Inc.

[116] C.S.Paparizos, W. Garside;S.R. Dolhyj, Catalytic conversion of lactic acid and ammonium lactate to acrylic acid. 1988, The Standard Oil Company.

[117] G.C.Gunter, R.H.Langford, J.E.Jackson, D.J.Miller, Ind. Eng. Chem. Res.1995. 34(3), 974-980.

[118] G.C.Gunter, D.J. Miller, J.E. Jackson, J. Catal., 1994. 148(1), 252-260.

[119] J.Zhang, J.Lin, X.Xu, P.Cen, Chin. J. Chem. Eng. 2008. 16(2), 263-269.

[120] J.-M.Lee, D.-W.Hwang, Y.K.Hwang, S.B.Halligudi, J.-S.Chang, Y.-H.Han, Catal. Comm., 2010. 11(15), 1176-1180.

[121] J.Zhang, Y.Zhao, X.Feng, X.Pan, J.Zhao, W.Ji, C.-T.Au, Catal. Sci. Techn., 2014. 4(5), 1376-1385.

[122] J.Zhang, Y.Zhao, M.Pan, X.Feng, W.Ji, C.-T. Au, ACS Catal., 2010. 1(1), 32-41.

[123] J.Zhang, Y.Zhao, X.Feng, X.Pan, J.Zhao, W.Ji, C.-T.Au, Catal. Sci. Techn., 2014. 4(5), 1376-1385.

[124] J.Peng, X.Li, C.Tang, W.Bai, Green Chem., 2014. 16(1), 108-111.

[125] C.Li, B.Wang, Q.Zhu, T.Tan, Appl. Catal. A: Gen., 2014. 487(0), 219-225.

[126] E.Blanco, P.Delichere, J.M.M.Millet, S.Loridant, Catal. Today, 2014. 226(0), 185-191.

[127] J.Lingoes, C.Villalobos; I. Dimitris, In Catalytic Conversion Of Lactic Acid To Acrylic Acid, T.P.G. Company, Editor. 2013.

[128] H.Wang, D.Yu, P.Sun, J.Yan, Y.Wang, H.Huang, Catal. Comm., 2008. 9(9), 1799-1803.

[129] J.H.Hong, J.-M.Lee, H.Kim, Y.K.Hwang, J.-S.Chang, S.B.Halligudi, Y.-H.Han, Appl. Catal. A: Gen., 2011. 396(1-2), 194-200.

[130] C.Tang, J.Peng, G.Fan, X.Li, X.Pu, W.Bai, Catal. Comm., 2014. 43(0), 231-234.

[131] T.Tsuchida, J.Kubo, T.Yoshioka, S.Sakuma, T.Takeguchi, W.Ueda, J. Catal., 2008. 259(2), 183-189.

[132] S.D.Sebti, R.Tahir, R.Nazih, A.Saber, S.Boulaajaj, Appl. Catal. A: Gen., 2002. 228(1-2), 155-159.

[133] M.Gruselle, T.Kanger, R.Thouvenot, A.Flambard, K.Kriis, V.Mikli, R.Traksmaa, B.Maaten, K.Tonsuaadu, ACS Catal., 2011. 1(12), 1729-1733.

[134] J. Lan, Z. Zhang. J. Ind. Eng. Chem. 2015, 23(0), 200-205.

[135] K.Zhao, B.Qiao, Y. Zhang, J.Wang, Chin. J. Catal., 2013. 34(7), 1386-1394.

[136] T.Hara, K.Mori, T.Mizugaki, K.Ebitani, K.Kaneda, Tetra. Lett., 2003. 44(33), 6207-6210.

[137] H.Zhou, J. Lee, Acta Biomater. 2011. 7(7), 2769-2781.

[138] K.Kurashina, G.L.de Lange, C. de Puttert, K.de Groot, Biomater., 1984. 5(4), 215-220.

[139] N.Zhang, T.Gao, Y.Wang, Z.Wang, P.Zhang, J.Liu, Mater. Sci. Eng: C, 2015. 46(0), 158165.

[140] M.Vallet Regi, D.Arcos, J. Mater. Chem., 2005, 15, 1509-1516.

[141] D.Laurencin, N.Almora-Barrios, N.H.de Leeuw, C.Gervais, C.Bonhomme, F. Mauri, W.Chrzanowski, J.C. Knowles, R.J.Newport, A.Wong, A.Gan, M.E.Smith, Biomater., 2011. 32(7), 1826-1837.

[142] M.Ben Osman, Sensibilité de la réaction de conversion de l'éthanol en $n$-butanol à la structure des hydroxyapatites : mode de fonctionnement. 2014, PhD thesis, Université Pierre et Marie Curie. p. 314.

[143] A.S.Posner, F. Betts, N.C. Blumenthal, Prog. Crys. Growth Charact., 1980. 3(1), 49-64.

[144] L.Silvester, J.-F.Lamonier, R.-N.Vannier, C.Lamonier, M.Capron, A.-S.Mamede, F.Pourpoint, A.Gervasini, F.Dumeignil, J. Mater. Chem. A, 2014. 2(29), 11073-11090.

[145] S.Diallo-Garcia, Hydroxyapatites, un système basique atypique modulable par la synthèse : vers l'identification des sites actifs, PhD thesis, 2012, Université Pierre et Marie Curie. p. 280.

[146] Y.Matsuura, A. Onda, K. Yanagisawa, Catal. Comm., 2014. 48(0), 5-10.

[147] T.Tsuchida, J.Kubo, T.Yoshioka, S.Sakuma, T.Takeguchi, W.Ueda, J. Japan Petrol. Inst., 2009. 52(2), 51-59.

[148] B.Yan, L.-Z.Tao, Y.Liang, B.-Q.Xu, ACS Catal. 2014. 4(6), 1931-1943. 
[149] Y. Matsuura, A. Onda, K. Yanagisawa, Catal. Today, 2014. 226(0), 192-197.

[150] A.M.Onda, Y. Matsuura, K. Yanagisawa, Method for synthesizing unsaturated carboxylic acid and/or derivative of same. 2012. US8772539 B2

[151] V.C.Ghantani, M.K.Dongare, S.B. Umbarkar, Green Chem., 2013. 15(5), 1211-1217.

[152] V.C. Ghantani, M.K. Dongare, S.B. Umbarkar, RSC Adv., 2014. 4(63), 33319-33326.

[153] B.Yan, L.-Z.Tao, Y.Liang, B.-Q.Xu, ACS Catal., 2014. 4(6), 1931-1943.

[154] C.Hammaecher, J.-F. Paul, J. Catal., 2013. 300(0), 174-182. 
Figure captions:

Figure 1. Impact of the propylene price variations on the price of acrylic acid in Europe $[15,16]$.

Figure 2. Scheme of the metabolic routes for the biosynthesis of acrylate from sugars. Reprinted with permission from [59].

Figure 3. Overall diagram of routes for the production of acrylic acid and acrylate esters from petrochemicals. Adapted from [12].

Figure 4. Possible occuring products during the conversion of lactic acid to acrylic acid.

Figure 5. Representation of the crystal structure of $X$ and $Y$ zeolites. Adapted from [95]

Figure 6. Representation of the different accessible sites to ions outside the crystal structure of NaY zeolites [105].

Figure 7. Representation of possible localisations of lanthanum according to the method of preparation of zeolites [107].

Figure 8. Evolution during lactic acid conversion time and acrylic acid selectivity over potassium modified zeolites. Adapted from [111].

Figure 9. Mechanism proposed by Huang et al. for the dehydration of lactic acid to acrylic acid over KX-modified NaY zeolites. Reprinted with permission from [110].

Figure 10. Representation of clusters formed by alkali $\left(\mathrm{X}^{+}\right)$and alkaline earth metals $\left(\mathrm{X}^{2+}\right)$ and oxygens in the crystal structure of NaY zeolites. Reprinted with permission from [113].

Figure 11. Assessment of the stability of the catalyst and its regeneration in air [122]: (a) first test carried out with fresh $14 \% \mathrm{NaH}_{2} \mathrm{PO}_{4} / \mathrm{NaY}$ for $28 \mathrm{~h}$, (b) second $8 \mathrm{~h}$ test carried out with the used catalyst. Reprinted with persmission from [122].

Figure 12. Stability over time of barium pyrophosphate during the dehydration of lactic acid to acrylic acid. Reprinted with permission from [130].

Figure 13. Representation in directions $a, b$ and $z$ of the hexagonal structure of hydroxyapatite. Adapted from [140]. 
Figure 14. Projection ab of the hydroxyapatite structure. Adapted from [141].

Figure 15. Stability over time of the catalyst Ca-Na-HAP(1.55) during the reaction of dehydration of lactic acid to acrylic acid. Reprinted with permission from [146].

Figure 16. Mechanisms proposed by Umbarkar et al. for the conversion of lactic acid to acrylic acid (a) and to acetaldehyde (b) over HAPs. Adapted from [152]. 
Captions schemes:

Scheme 1. $D(-)$ and $L(+)$ enantiomers of lactic acid [6]

Scheme 2. Scheme of the dehydration reaction of lactic acid to acrylic acid.

Scheme 3. Lactic acid production from acetaldehyde via actonitrile. Adapted from [23].

Scheme 4. Various resources envisaged for lactic acid production processes via the chemical route. Adapted from [35].

Scheme 5. Conversion mechanisms of trioses to lactic acid or alkyl lactate proposed by Dusselier et al. [35]. Adapted from [35]

Scheme 6. Steps proposed for the mechanism of synthesis of lactate from propanal. Adapted from [42].

Scheme 7. Simplified scheme of the direct route for metabolic reduction in $C$. Propionicum. Adapted from [56].

Scheme 8. Equations for the one- or two-step production of acrylic acid from propene. Adapted from [12].

Scheme 9. Scheme of the dehydration of lactic acid to acrylic acid. 
Captions Tables:

Table 1. Data of TPD-NH $\mathrm{N}_{3}$ over $\mathrm{NaY}$ and $\mathrm{KNaY}$ zeolites [101]

Table 2. Catalytic performances of $\mathrm{NaY}$ and $\mathrm{KnaY}$ for the dehydration of methyl lactate to methyl acrylate [101]

Table 3. Selectivities observed by Huang et al. over zeolites modified by lanthanide impregnation [103]

Table 4. Assessment of the acidity of zeolites by TPD- $\mathrm{NH}_{3}$ [103]

Table 5. Results of catalytic tests carried out by Huang et al. over zeolites modified by potassium [111]

Table 6. Acid properties of K/NaY zeolites (Si/Al: 2.5) determined by TPD-NH [109]

Table 7. Basic properties of K/NaY zeolites (Si/Al: 2.5 ) determined by TPD-CO 2 [109]

Table 8: Results of tests on catalytic dehydration of lactic acid over sodium phosphate-based catalysts supported on zeolite nanocrystals [123]

Table 9: Different calcium phosphate phases and corresponding $\mathrm{Ca} / \mathrm{P}$ ratios [142] 


\section{Graphical Abstract:}

This review presents recent developments in the study of dehydration of lactic acid to acrylic acid. The current state of the art on this subject is presented and critically commented. It is based on the most recent publications on the topic, which are discussed in details with respect to the observed catalytic performances.
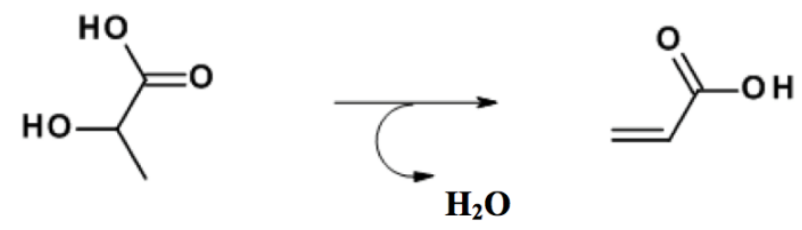